Portland State University

PDXScholar

$5-11-1992$

\title{
A Diagnostic Analysis of Elementary Principal' Practices Which Serve Youth At-Risk of School Failure
}

Rikki Kenneth Patrick

Portland State University

Follow this and additional works at: https://pdxscholar.library.pdx.edu/open_access_etds

Part of the Elementary and Middle and Secondary Education Administration Commons Let us know how access to this document benefits you.

\section{Recommended Citation}

Patrick, Rikki Kenneth, "A Diagnostic Analysis of Elementary Principal' Practices Which Serve Youth AtRisk of School Failure" (1992). Dissertations and Theses. Paper 1199.

https://doi.org/10.15760/etd.1198

This Dissertation is brought to you for free and open access. It has been accepted for inclusion in Dissertations and Theses by an authorized administrator of PDXScholar. Please contact us if we can make this document more accessible: pdxscholar@pdx.edu. 


\section{A DIAGNOSTIC ANALYSIS OF ELEMENTARY PRINCIPALS' \\ PRACTICES WHICH SERVE YOUTH AT-RISK \\ OF SCHOOL FAILURE}

by

RIKKI KENNETH PATRICK

A dissertation submitted in partial fulfillment of the requirements for the degree of

DOCTOR OF EDUCATION in

EDUCATIONAL LEADERSHIP:

ADMINISTRATION AND SUPERVISION

Portland State University

(C) 1992 
TO THE OFFICE OF GRADUATE STUDIES:

The members of the Committee approve the dissertation of Rikki Kenneth Patrick presented May 11, 1992.
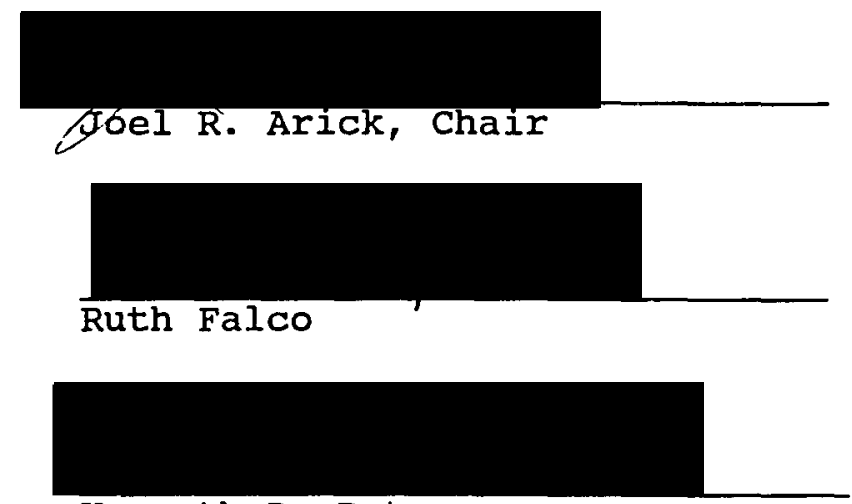

Kenneth D. Peterson
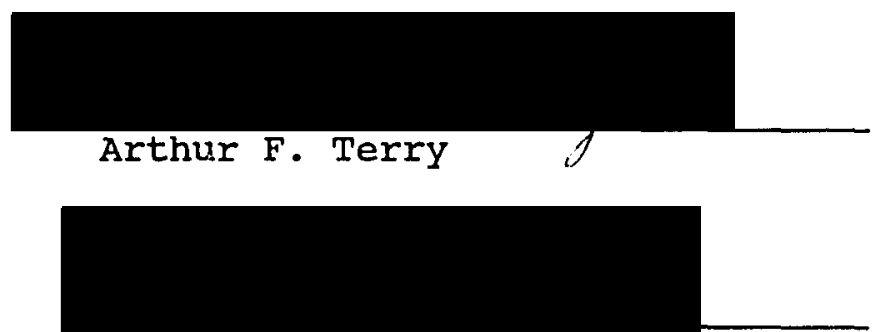

Nancy Moroloff 00

APPROVED:

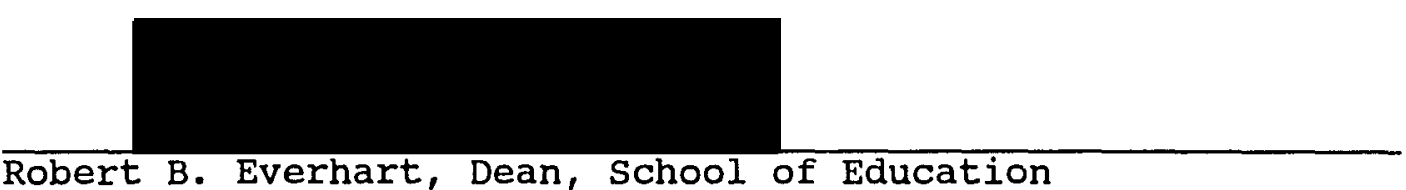

Robert B. Everhart, Dean, School of Education

C. William Savery, Vice Provost for Graduate studies and Research 
AN ABSTRACT OF THE DISSERTATION OF Rikki Kenneth Patrick for the Doctor of Education in Educational Leadership: Administration and Supervision presented May 11, 1992.

Title: A Diagnostic Analysis of Elementary Principals' Practices which Serve Youth At-Risk of School Failure.

APPROVED BY THE MEMBERS OF THE DISSERTATION COMMITTEE:

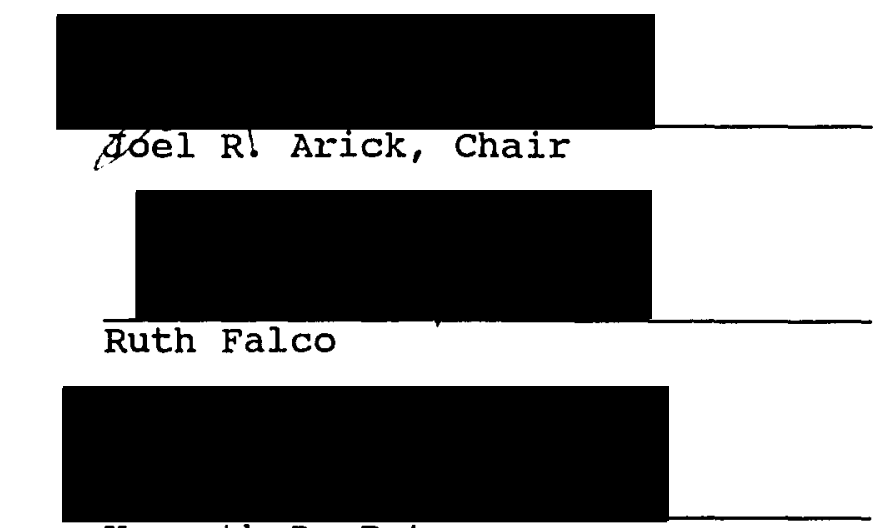

Kenneth D. Peterson

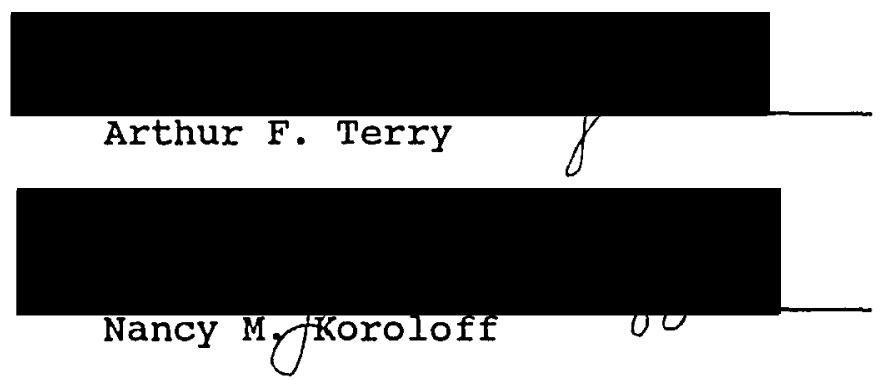

This study provides a description of the practices elementary school principals employ to reduce the likelihood that at-risk youth will actually experience school failure. 
The problem investigated in this study is reflected in this broad question: What is the relationship of principals' practices to the provision of service for at-risk youth? Differences in the importance and frequency of use of practices by principals were compared. Variables such as school size, percentage of students who are eligible for free lunch, percentage of students who are at-risk, student mobility, and principal's rating of how successfully their school is serving at-risk youth were also investigated. Thirty percent of the elementary principals employed in the metropolitan area of Portland, oregon were randomly selected to participate in this study.

The research design was descriptive. Data were collected from the Critical Principal Practices Profile, a questionnaire developed by the researcher and five practitioners after an extensive review of related literature.

Using a 4-point scale, principals indicated the importance and frequency of use of principals' practices for the provision of service for at-risk youth.

Eighty-three percent of the selected principals completed and returned the survey. Of the responding principals' schools: 25.98 had a student population greater than 600 students, $27.8 \%$ had more than $50 \%$ of the student body eligible for free lunch, and $43.5 \%$ had more than $32 \%$ of the student body at-risk of school failure. 
A number of statistical treatments were performed in analyzing the data. According to the respondents, "Selection of Service Delivery Patterns" emerged as the most important practice $(\underline{M}=3.65)$ and the most frequently used practice $(\underline{M}=3.21)$ for serving at-risk youth. The practice "Selection of Service Delivery Patterns" was described by five explanatory items: identifying at-risk youth, requiring the modification of curricula, identifying suspension and expulsion alternatives, monitoring student performance, and implementing retention alternatives. The principals' practices and the school demographics were compared using an ANOVA. Associations reaching a significant level were found between the independent and dependent variables; however, the importance and frequency of use patterns reported by the principals could not be consistently explained simply by school demographics. 


\section{ACKNOWLEDGEMENTS}

I wish to extend my sincere appreciation to my dissertation committee--Dr. Joel Arick, Dr. Ruth Falco, Dr. Nancy Koroloff, Dr. Art Terry, and Dr. Ken Peterson--whose guidance and input into this research project proved invaluable. My very special thanks go to Dr. Arick, Chair of the committee. Not only has he served as a terrific chair, but he has also been mentor, professor, friend, and source of encouragement.

To the principals who assisted me with the survey; to my colleagues from Portland Public Schools and the Hillsboro Elementary School District, I extend my indebtedness for your professional interest and friendship.

I am, most of all, grateful to my wife, Laure, and my daughters, Emily, Rachel, and stephanie, whose love and unwavering support carried me through demanding days. 
TABLE OF CONTENTS

PAGE

ACKNOWLEDGEMENTS. . . . . . . . . . . . . . . . . iii

LIST OF TABLES. . . . . . . . . . . . . . . . . . vii

CHAPTER

I

INTRODUCTION AND OVERVIEW. . . . . . . . . 1

Introduction . . . . . . . . . . . 1

Background . . . . . . . . . . . 1

Statement of the Problem . . . . . . 6

Research Questions . . . . . . . 6

Significance . . . . . . . . . . 7

Operational Definitions. . . . . . 8

Summary of the chapters. . . . . . . 9

II REVIEW OF RELATED LITERATURE . . . • . . • . 11

Introduction and overview of the Role of the Elementary School

Principal. . . . . . . . . . . 11

Implications for School Principals

as School Leaders Capable of

Providing Service for Students . . . 14

Practices Associated with the

Provision of Service Shown to

be Effective in Serving Youth

At-Risk of Leaving School Before

High School Graduation . . . . . 15

Summary . . . . . . . . . . . 21

III METHODOLOGY . . . . . . . . . . . 23 
Research Design . . . . . . . . 23

Sampling Technique. . . . . . . . . 24

Ethical Considerations. . . . . . . 26

Instrument. . . . . . . . . . . 26

Reliability and Validity of Instrument. . . . . . . . . . 27

Statistical Analysis. . . . . . . . 32

Limitations of the study. . . . . . . 33

Summary . . . . . . . . . . . . 34

FINDINGS. • • . . . . . . . . . . . 35

Demographic Information . . . . . . 35

Analysis of Research Questions. . . . . 41

Research Question \#1
Research Question \#2
Research Question \#3
Research Question $\# 4$
Research Question \#5
Research Question \#6
Research Question \#7

Multiple Regression Analysis. . . . . 59

Research Question \#8

Summary . . . . . . . . . . . 64

$\mathrm{V}$ SUMMARY, INTERPRETATIONS, AND

RECOMMENDATIONS . . . . . . . . . . 66

Findings and Discussion . . . . . . . 67

Research Question \#1

Research Question \#2

Research Question \#3

Research Question \#4

Research Question \#5

Research Question \#6

Research Question \#7

Research Question \#8 
Limitations of the Findings . . . . . 79

Interpretations . . . . . . . . 80

Recommendations . . . . . . . . 84

Implications for the Educational Community

Implications for Future

Research

REFERENCES . . . . . . . . . . . . . . . . . 88 APPENDICES

A PILOT STUDY . . . . . . . . . . . . . . . 93

B INSTRUMENT AND COVER LETTERS. . . . . . . . . 95

C PRETEST/POSTTEST CORRELATIONS . . . . . . . 100

D RANK, MEAN SCORES, AND STANDARD DEVIATION IMPORTANCE AND FREQUENCY OF USE OF EXPIANATORY ITEMS FOR EACH PRINCIPAL PRACTICE. . . . . . . . . . . . . 103

E MEAN SCORES AND RANK OF IMPORTANCE AND FREQUENCY OF USE OF EXPLANATORY ITEMS . . . . . . . . . . . . . . . 108 
LIST OF TABLES

TABLE

PAGE

I School Demographics . . . . . . . . 36

II Student Demographics I. . . . . . . . . 38

III Student Demographics II . . . . . . . . 38

IV Teacher Demographics. . . . . . . . . 40

$\mathrm{V}$ Rating of Provision of Service for At-Risk Youth............ 40

VI Mean Scores and Rank of Importance of Principal Practices... . . . . . . 42

VII Mean Scores and Rank of Frequency of Use of Principal Practices. . . . . . 43

VIII Mean Scores and Rank of Importance and Frequency of Use of Principal Practices .. . . . . . . . . . . 44

IX Selection of Service Delivery Patterns Practice: Mean Scores and Rank of Importance and Frequency of Use of Specific Items. . . 46

$X$ Rank, Mean Scores, and Standard Deviation of Highest Principals' Ratings for Importance and Frequency of Use of Explanatory Items for Each Principal Practice. . . . . . . . . . . . 47

XI Association of Principal Practices with School Size... . . . . . 50

XII Association of Principal Practices with Percentage of Students Eligible for Free Lunch. . . . . . . . . . . 52

XIII Association of Principal Practices with Percentage of At-Risk Youth . . . . . 55 
viii

XIV Association of Principal Practices with Percentage of students Attending Respondent's School for at Least

One Year. . . . . . . . . . . . 58

XV Selection of Service Delivery Patterns

Practice: Stepwise Multiple

Regression of Principals' Rating

of the Importarice . . . . . . . . . 61

XVI Association of Principal Practices

with Principals' Perception of How Successfully School Serves At-Risk

Youth . . . . . . . . . . 63 


\section{CHAPTER I \\ INTRODUCTION AND OVERVIEW}

\section{INTRODUCTION}

The purpose of this study is to investigate principal practices related to the provision of service shown to be effective in serving elementary students at-risk of leaving school before high school graduation. Little is known about principals' practices associated with the provision of service for at-risk students (Pallas, 1989; Sanacore, 1988). This study attempts to fill this void. The study is directed toward one major area of inquiry: a description of the principal's practices intenced to provide service for at-risk elementary students.

This first chapter of the study presents the background for the project, operational definitions, and the statement of the problem, and the research questions. The chapter concludes with an examination of the significance of the study and a summary of forthcoming chapters.

\section{BACKGROUND}

The United States is said to be a "Nation at Risk," and many of our youth are also at-risk. Of the 4- and 5-year-olds in today's United States, the potential workers 
in the year 2010, one in four has a mother working full-time outside of the home and receives inadequate child care; one in four lives in a family whose income is below the poverty level; one in five is born out of wedlock; one in six lives in a family where neither parent is employed; one in six is not covered by medical insurance; and one in seven will most likely drop out of school (Children's Defense Fund, 1990; Green \& Smith, 1987; Hodgkinson, 1985). Many of the youth in the United States are on an endangered list. Prospects for their success are remote unless strategies are developed to reverse the effects of conditions illustrated by these startling statistics (Hahn, Danzberger, \& Lefkowitz, 1987). our young people are faced with chronic and persistent deprivation from which they see no escape. Many lead lives of great hardship, with little access to health care, ample food, sufficient clothing, or adequate housing. Possessing the aforementioned attributes does not determine school or societal failure; however, it is more difficult for youth to succeed under the burden of social, economic, and physical adversity. Unless we can successfully teach our young people how to read, write, compute, and think, they will be handicapped throughout their academic and occupational careers (Barr \& Parrett, 1992; Green \& Baker, 1986). One of the issues of major concern is therefore the number of youth attending school who are "at-risk" of dropping out of the 
educational enterprise or graduating high school without adequate skills.

It is a basic value of our society that education is the key to success; this belief is particularly true now. The employment opportunities for individuals with minimal academic skills are severely limited. The United states has experienced a $40 \%$ decline in unskilled labor positions since 1947. This decline has been accompanied by an $81 \%$ increase in the share of employment in the areas of finance, insurance, high tech, real estate, and various service industries, all of which depend heavily on one's ability to make effective and efficient/use of thinking, reasoning, and academic skills (California state Department of Education, 1986, p. 2; National Poljicy Institute, 1988). The transition frorn a nation needing an unskilled labor force to one requiring|academic and thinking skills, coupled with the statistics identifying our society as aging rapidly, indicates that we have a mandate to prevent our youth from dropping out of school. In 1950, 17 workers paid the social security benefits of each retiree. By 1993, only three workers will provide the funds for each retiree, and one of those three will be a member of a racial or ethnic group currently characterized by poor graduation rates (Gruskin, Campbel1, \& Paulu, 1987; Institute for Educational Leadership, 1986). Our nation is dependent upon a smaller 
and better educated population to support the policies and programs that sustain a democratic society.

students who drop out of school also negatively impact subsequent generations of Americans. Dropouts are less likely to acquire and keep jobs and their earning power is greatly reduced. Students who dropped out of the class of 1981 will experience a total lifetime earning loss of approximately 228 billion dollars which will account for a tax revenue loss of over 68 billion dollars. Children of dropouts have a higher incidence of poverty than their counterparts living in families where one or both parents are high school graduates. In $1982,39 \%$ of the children living in families headed by dropouts were also living in poverty. Only $7 \%$ of the children living in a family headed by high school graduates were living in poverty (Association of Black School Educators, 1988).

With the awareness of the tremendous social and economic costs incurred by youth who drop out of school, principals are being directed to solve the problem immediately. In order to assist schools and other service providers, elementary school principals require information about the student who is at-risk of dropping out of school and the practices which increase the chances that youth who are at-risk of dropping out of school will complete formal education programs. 
The urgent need to provide successful service for at-risk youth is driven by the high cost to the individual student and to society which accompanies each dropout statistic. School principals can use this necessity to dramatically improve their service delivery systems. If exemplary dropout prevention and recovery practices can be established, then principals will be more able to deliver the same quality of service for all of our youth, regardless of how "at-risk" of dropping out they may be.

This imperative coupled with the sincere concern of principals to manifest practices which effectively serve their at-risk student population provided the impetus for the researcher to form a small study group of five principals. (Other than the characteristics of current employment as a elementary principal and a willingness to participate, there were no qualifications for membership.) The purpose of the study group was to gain an understanding about the practices principals employ to provide service for at-risk youth. As a part of the study group, an intensive review of literature and a thorough examination of principals' practices relating to serving at-risk youth was completed. One outcome of this effort was the production of a survey designed to validate and extend the work of the study group and the development of a definite problem statement to guide the research project. 
STATEMENT OF THE PROBLEM

The purpose of this study is to investigate the relationship of principals' practices to the provision of service for at-risk youth.

The problem investigated in this study is reflected in this broad question: What is the relationship of principals' practices to the provision of service for at-risk youth?

RESEARCH QUESTIONS

With regard to this purpose, it was possible to develop research questions that addressed the study's problem. The specific research questions investigated are: Research Question \#1: What practices do principals perceive as important in serving at-risk youth in elementary schools?

Research Question \#2: How frequently are principal practices designed to serve at-risk youth in use in elementary schools?

Research Question \#3: What are the differences between the principals' ratings of the importance and frequency of use of practices designed to serve at-risk youth?

Research Question \#4: What principal practices which serve at-risk youth are associated with elementary school size? 
Research Question \#5: What principal practices which serve at-risk youth are associated with percentages of elementary students eligible to receive free lunch?

Research Question \#6: What principal practices which serve at-risk youth are associated with percentages of at-risk youth attending elementary schools?

Research Question \#7: What principal practices which serve at-risk youth are associated with the percentages of students attending their current school for at least one year?

Research Question \#8: What principal practices which serve at-risk youth are associated with elementary schools successfully serving at-risk youth?

\section{SIGNIFICANCE}

This study furnishes a description of principals' practices intended to provide service for at-risk youth. The information gained by answering the research questions supplies valuable information to elementary school principals who are planning or implementing services designed to prevent at-risk youth from becoming dropouts. Finding sufficient empirical data to identify principals' practices associated with the provision of service for at-risk youth is a monumental challenge. Mann (1986) writes, "We have better national descriptions of youth at-risk than we have local descriptions of practices" 
(p. 68). Mann continues by discussing that although there is a plethora of programs considered helpful to dropout prevention, little research has been conducted to evaluate principal practices affecting at-risk youth. Many at-risk youth services considered "effective" are based solely on program descriptions. One needs to look to principals who work with at-risk children and document specific practices that work for their students (Texas Education Agency, 1988). As Hodgkinson (1986) notes, ". . there exists a major need to coordinate and share information" (p. 4) concerning successful dropout prevention practices.

\section{OPERATIONAL DEFINITIONS}

The following terminology is used in this study. At-Risk: The term "at-risk" refers to attributes a child enrolled in school possesses which categorize him or her as at-risk of becoming a dropout. Duhon and Mouton (1985) define a "dropout" as "any student who leaves school prior to high school graduation for any reason except death" (p. 9). Several authors suggest characteristics which are associated with dropouts and, therefore, with at-risk students: absenteeism, truancy, frequent tardiness, poor grades, low test scores, limited extracurricular participation, and discipline problems (California state Department of Education, 1986, p. 3); truant and academically failing (Green \& Baker, 1986, p. 14; Prophet, 
1986; Quay \& Allen, 1982); marginal academic performance (Hahn, 1987, p. 259); students behind in grade level, older than classmates, and who exhibit behavioral difficulties (Staff of Iinden Elementary School, 1988); and students academically failing in the elementary grades (wisconsin Vocational studies Center, 1981). In this study, "at-risk" is defined as elementary students who are developmentally functioning at least one year younger than classmates, academically functioning at least one year behind grade level, or exhibiting behaviors which initiate intervention by staff other than the classroom teacher (i.e. counselor, principal, social worker). For the purposes of this study, at-risk youth who have an active special education Individualized Educational Program (IEP) are excluded. Principal's Practice: The execution of a purposeful or undeliberated action by an elementary school principal intended to provide service for at-risk students. Elementary School: Any of several public educational institutions, preceding secondary school, giving a course of instruction for children in grades pre-kindergarten through grade eight. This includes, but is not limited to, primary schools and grade schools.

\section{SUMMARY OF THE CHAPTERS}

The major purpose of the study is to investigate principal practices associated with the provision of service 
for at-risk youth. Chapter I provides an introduction, operational definitions, the background, a problem statement, the research questions, and the significance of the study. A review of the pertinent literature is presented in Chapter II. Chapter III discusses the research methodology, design, and data analyses. The findings are presented in chapter IV. Chapter V summarizes the study and presents conclusions and recommendations based on the findings. The study concludes with the appendices and a listing of references. 
CHAPTER II

REVIEW OF RELATED LITERATURE

This review of related literature is presented in three sections: (a) introduction and overview of the role of the elementary school principal, (b) implications for school principals as school leaders capable of providing service for students, and (c) practices associated with the provision of service shown to be effective in serving youth at-risk of leaving school before high school graduation.

INTRODUCTION AND OVERVIEW OF THE ROLE OF THE ELEMENTARY SCHOOL PRINCIPAL

Attempts at describing the roles of the elementary principal began with the inception of the position. As a response to a growing student population, the modern American principalship initially appeared in urban schools in the mid-nineteenth century. School boards created the position of principal to "carry out orders, look after the building, maintain decent relations with adults and children, . . manage the curriculum and supervise the instruction" (Cuban, 1988, p. 54). The dominant roles of the principalship have remained basically unchanged since the creation of the position: principal as bureaucrat and principal as instructional leader (Tyack \& Hansot, 1982). 
The role of a bureaucrat refers to the administrative responsibilities of a principal, including numerous clerical and maintenance tasks. A principal also is expected to simultaneously supervise staff and govern the school's curriculum and instruction (Tyack \& Hansot, 1982).

Cuban (1988) delineates three roles of the modern principal: instructional, managerial, and political. The instructional role implies that a principal should be a pedagogical expert, assisting teachers to improve instruction. A principal is demonstrating the managerial role while completing tasks associated with district and school policies. The directions dictated by these roles are completely opposite. Managers are required to maintain organizational stability, and instructional leaders aim to alter existing teacher and student beliefs and behaviors to achieve school goals. For principals, the political role is the attempt to anticipate and manipulate public and organizational expectations to achieve school goals (Burlingame, 1985).

Another description of the role of the elementary principal characterizes the principal as an administrator orchestrating the social system of a school. A social system is defined as a set of interacting personalities bound together by social relationships (Getzels \& Guba, 1957; Hoy \& Forsyth, 1986). It is characterized by interdependence of elements, differentiation from its 
environment, complex networks of social relations, individual actors motivated by their personalities, a distinctive unity that exceeds its component parts, and interaction with its environment (Getzels \& Guba, 1984; HoY \& Miskel, 1987). The concept of a social system is a general one; however, it can be applied to elementary schools which are an example of one specific social organization (Jensen, 1954; Owens, 1987; Parsons, 1956). Working within a social system, the principal's role is defined as the set of behavioral expectations which interrelates the actions of individuals to other individuals in the school (Hoy \& Miskel, 1987). Getzels and Guba (1957), in their pioneering work, stressed the importance of congruence among actions in the school's social system to promote the attainment of organizational goals. The supervisor of the social system--the principal, in the elementary school--is vested with the responsibility of implementing practices which intend to meet the goals of the school (Owens, 1987). Achievement of organizational goals is dependent upon the extent to which the principal is effective in influencing the actions of others present in the school to attain these goals.

The role of the elementary school principal is remarkably complex and a topic of much debate at the theoretical level. However, effective schools research and subsequent research is clear in forcefully implying that the 
role of the principal is central to the success or failure of an elementary school (Blumberg, 1987; Blumberg \& Greenfield, 1986; Dwyer \& Smith, 1987).

\section{IMPLICATIONS FOR SCHOOL PRINCIPALS AS SCHOOL LEADERS CAPABLE OF PROVIDING SERVICE FOR STUDENTS}

Elaborating on the definition of the roles of the elementary principal, researchers have recently focused their work on the principal's practices and how these practices influence student outcomes. Studies of this type began with the work of Griffiths (1959). Griffiths found that there was a significant lack of practice descriptions for principals as they work in their organization--or as he states, "administrators . . in action" (p. 34). He engaged in studies to fill this research void. As an outcome of his efforts, Griffiths concluded that principals' practices can affect organizational outcomes.

In the tradition of Griffiths, Bossert, Dwyer, Rowan, and Lee (1982) also study the management practices of the principal. They determine that principals' practices have both direct and indirect effects on the specific organizational outcome of student success in school, and that a principal can exhibit specific management practices to affect specific schooling outcomes. Their study concludes that routine and non-routine practices of the principal directed at influencing school organizational 
climate and instructional organization can, in turn, influence schooling outcomes for students.

Dwyer (1985) continues to build on his earlier

collaborative work with Bossert and concludes that

principals' practices can set conditions for prompting

desired student behaviors. Successful principals are found to design routine practices which systematically "progress incrementally toward their goal" (p. 15).

This study attempts to build upon the works of Griffiths (1959), Bossert et al. (1982), and Dwyer (1985) by attempting to identify elementary principals' practices which can positively influence schooling outcomes for at-risk youth.

\section{PRACTICES ASSOCIATED WITH THE PROVISION OF SERVICE SHOWN TO BE EFFECTIVE IN SERVING YOUTH AT-RISK OF LEAVING SCHOOL BEFORE HIGH SCHOOL GRADUATION}

The issue of how to provide effective practices for at-risk youth has recently emerged as a national focal point for principals (Texas Education Agency, 1989b). This section of the literature review discusses the characteristics of schools associated with at-risk youth and the attributes of practices successful in serving at-risk youth.

Researchers have begun to identify school characteristics as factors which contribute significantly to the at-risk status of students (Green \& Baker, 1986; Wehlage 
\& Rutter, 1986). An example of the research which identifies school-controlled factors which increase the youth population at-risk of dropping out has been provided by Wehlage and Rutter. They find that socioeconomic status and school performance are minor variables in determining who is at-risk or who drops out. Students' perceptions about teacher interest in them as well as the effectiveness and fairness of school discipline is a critical factor in whether a student drops out or remains in school. Wehlage and Rutter suggest that the phenomena of at-risk students and dropouts is better conceived when certain school conditions are addressed. Regardless of other factors, it is important to note that alienation from the school itself is a common characteristic of at-risk and early leaver youth.

Additional evidence for the role that schools play in affecting at-risk youth is cited by Green and Smith (1987). This study finds that school leaving was highly correlated with the school attended. Their analysis of outcomes among students who had been forced to transfer because of school closures is particularly poignant; dropout rates from a neighborhood were cut in half when students entered a different school.

MCDill, Natriello, and Pallas (1986) identify characteristics of schools which have high dropout rates. They report that these schools: 
1. Have high rates of suspension;

2. Are large in size;

3. Have a high proportion of economically

disadvantaged ethnic and racial minority students;

4. Have poor teacher/administration cooperation; or

5. Have a high rate of transiency.

These findings are consistent with the effective schools research, which developed as a response to the idea that low achievement by poor children was due to certain inherent disabilities. This research and the strategies that have emerged from it emphasize the potential of schools to overcome the influence of student background characteristics and to reduce the number of students who are not successful in school (Green \& Baker, 1986; Texas Education Agency, 1988).

The urgency of successfully identifying at-risk children in order to adequately meet their needs must be balanced with the professional goal of avoiding the possible damage done to students by such labels as "at-risk." More harm than benefit may result if dropout prevention programs result in stigmatizing at-risk children by labelling them as "underachievers" and placing them in "special groups." According to a California state Department of Education report (1986), if a student is predicted to be a potential dropout, the labelling itself has consequences, not all of which are helpful to the child. However, ignoring obvious 
symptoms that a student is exhibiting behaviors associated with at-risk youth may also produce undesirable outcomes ( $p$. 4).

Mann (1986) emphasizes that the formulation of dropout prevention and recovery practices needs to begin with finding out what works best. Wehlage and Rutter (cited in Green \& Baker, 1986) believe that successful practices can and should be developed using a baseline of informational components, such as the percentage of at-risk youth attending school, students possessing competencies in basic skills, the currently successful intervention strategies. Although there are few data that detail what works in terms of specific practices, researchers report several characteristics that are common across the multitude of practices which are designed to reduce dropout rates. Green and Baker (1986) review 18 effective program reports and formulate a list of shared characteristics of participant practices. A summary of their findings is as follows:

1. Administrative Leadership: Local programs cite the necessity of having a principal guiding and leading the building efforts and a district administrative staff supportive and committed to the practices that reduce the at-risk population.

2. Staff Development: Staff should be trained in curriculum which is challenging, relevant, and meaningful to at-risk students. Teachers need a repertoire of activities 
based on real-life experiences, and should be afforded several opportunities to learn and practice new strategies of instruction.

3. Personnel: Programs need to be staffed with caring teachers who have the ability to establish rapport and develop relationships with students.

4. Methodology: Programs should be small with a student/teacher ratio not exceeding 20 to 1 . Instruction should be individualized in terms of pacing, ability, and content. Teachers must set clear expectations and standards based on realistic goals and the individual needs of the at-risk student.

Practices must be attractive to youth and teachers alike, and should deliver an inventive curriculum which can provide students with the knowledge, services, and experiences that stimulate cognitive, personal, and social growth (Texas Education Agency, 1988; Wehlage, Rutter, \& Turnbaugh, 1987).

Hahn et al. (1987) emphasize, in Dropouts in America: Enough is known for Action, that it is not practical to formulate broad district-wide practices to meet the needs of at-risk youth attending a particular school. However, it is critical to be prepared to identify and respond to different segments of the at-risk population within each neighborhood elementary school. Efforts to intervene must respond to each child's distinctive and varied requirements (Texas 
Education Agency, 1989a). The familial, peer, social, economic and school-related problems of each at-risk child require responses to that individual's entire environment. We need "far greater integration and coordination of the social services, child welfare, and educational systems than has been attempted" (Hahn, 1987, p. 263).

Rumberger (1983) suggests that comprehensive practices to serve at-risk youth need to include an appropriate mix of educational and noneducational services, accurate identification of at-risk youth, comprehensive and varied components to meet the needs of various at-risk students, and elementary practices designed for early intervention and recovery.

Mann (1986) emphasizes that complex problems inherent in the at-risk youth population require comprehensive principal practices that ambitiously attempt to coordinate several loosely coupled elements. Practitioners also agree that effective dropout prevention practices cannot be based on a single factor such as remedial instruction or social service interventions (Texas Education Agency, 1988). Many educators feel that dropout prevention efforts must be established in the elementary schools . . . If an intervention effort is implemented soon enough, it is hoped that the student might be helped before a cycle of failure or negative behavior is fully developed. (Wisconsin Vocational Studies Center, 1981, p. 5) 
The active support of the community is also an important, even key, ingredient to the success of a dropout prevention program.

To gain this support, the design of an effort should reflect school and community values and should incorporate a plan for developing good school/community relations. (Wisconsin Vocational studies Center, 1981, p. 5)

\section{SUMMARY}

The literature reveals that there are several characteristics common to practices that have been successful in working with at-risk youth. Most of the characteristics must be school-specific and are associated with the leadership practices of the principal. Based upon this literature, a survey has been developed to assess principals' perceptions of these administrative practices and their importance in the effective support of serving at-risk youth and their degree of implementation in the principals' schools.

The literature identifies several practices that influence the effectiveness of at-risk youth programs. The researcher and five practitioners sorted these into seven categories: organizational support for programs serving at-risk youth, selection of appropriate service delivery patterns, assignment of personnel, development of a responsive staff development program, school personnel acceptance of at-risk youth, parental involvement, and 
community involvement. Each category was defined using a list of specific practices that the literature disclosed as important to successful practices in the provision of service for at-risk youth. Information gathered from the literature also indicates that school characteristics have a profound effect on at-risk youth programs implemented in schools. To complete the survey, the practitioners and the researcher included a section requesting information concerning these characteristics.

Finally, this review of the literature establishes two factors which are pertinent to the present study: (a) there is an insufficient amount of recent research data to comprehensively inform principals how their practices can | assist in the successful provision of service for at-risk youth in their buildings; and (b) the present study is unique among the existing studies of at-risk youth programs as it attempts to describe specific principal practices that can be performed to provide services which can positively । influence schooling outcomes for at-risk youth. 
CHAPTER III

METHODOLOGY

The purpose of this study is to investigate the relationship of principals' practices to the provisions of service for at-risk youth. Decisions regarding the methodology were completed upon the basis of applicability to the completion of the study's purpose. This chapter describes the procedures employed in the: (a) research design, (b) sampling techniques, (c) ethical considerations, (d) design of the instrument, and (e) statistical analysis. Limitations of the study and the summary are also presented.

\section{RESEARCH DESIGN}

The research design of the study is descriptive. Descriptive studies seek knowledge about relationships between variables (Van Dalen, 1979), and attempt to collect data from members of a population in order to determine the current status of that population with respect to one or more variables (Gay, 1987). Descriptive research possesses attributes which distinguish it from other types of research: research question development and testing, variable definitions, relationship analysis between nonmanipulated variables, accurate descriptions of 
procedures to facilitate replication, and generalizations extrapolated from logical methods of reasoning (Best \& Kahn, 1986). Descriptive research is different from assessment and evaluation because of its attention to variable relationships and the answering of questions related to these relationships (Ary, Jacobs, \& Razavieh, 1985). The methods of descriptive research are appropriate to the field of education, where ethical and legal considerations contraindicate introduction or manipulation of variables necessary for experimental research (Newman \& Newman, 1977).

\section{SAMPLING TECHNIQUE}

The subjects of this study were elementary school principals serving in the Portland, oregon metropolitan area.

Principals were chosen as respondents to the instrument because the role of the principal is critical to the school success or failure of elementary students and the principal is one of the few professionals employed at a school who is qualified to comment on the global operation of a particular school (Barth, 1976; Blumberg \& Greenfield, 1986).

To insure a representative sample of elementary principals in the Portland, oregon metropolitan area and a sufficient number of respondents were surveyed, the following sampling technique was employed. 
Approximately $30 \%$ or 130 of the 463 elementary principals employed in the metropolitan area of Portland, oregon were randomly selected using the Lotus 123 program. The U. S. Office of Management and Budget (1983) publication, Metropolitan Areas and Component Counties, provided the names of the counties included in the metropolitan area of Portland, oregon. Principals were identified from the state school directories of Washington (Krohn, 1990-1991) and Oregon (Oregon Department, 1990), and the U. S. Department of Education (1984) resource manual, Universe of Public School Districts.

Surveys were mailed with an explanatory cover letter to the sample population of elementary school principals. Each respondent was provided a postage-paid return envelope. The principals were asked to return the questionnaire within three weeks of arrival. To maximize the return rate, a follow-up letter and second copy of the survey was sent to the nonresponding subjects one month after the initial mailing. Sudman (1983) finds that employing the aforementioned strategy ensures a higher rate of return. of the identified principals, 108 returned completed surveys for a return rate of approximately $83 \%$. Sudman (1983) concludes that a response rate of $80 \%$ is sufficient to ensure an adequate degree of confidence when surveying a special population in a specific geographic location. The response rate provided the study with a representative 
sampling of the elementary school principals in the Portland, Oregon metropolitan area.

\section{ETHICAL CONSIDERATIONS}

Elementary principals completed the Isurvey voluntarily. Individual data was secured by the researcher and was destroyed upon completion of the study. All information gathered through the study--including identification of elementary schools, school districts, cities, and states--will remain strictly confidential.

\section{INSTRUMENT}

Data were collected from the Critical Principal Practices Profile (Appendix B.). The Critical Principal Practices Profile is a self assessment instrument developed by a team of elementary school principals and the researcher to provide a thorough analysis of prinoipall practices that impact services for at-risk youth.

Data gathered from this instrument include:

1. School Demographic Information

a. grades attending school

b. total number of students

c. total number of certified teaching staff

d. percentage of student body receiving free

lunch

e. ethnicity of certified staff and student body 
f. percentage of at-risk students

g. percentage of student body suspended or

expelled

h. percentage of teachers disciplined

i. district high school dropout rate

i. percentage of student body attending school

for at least one year

2. Level of Importance and Frequency of Use of Principal Practices.

The seven categories of principal practices are: organizational Support for Programs Serving At-Risk Youth, Selection of Appropriate Service Delivery Patterns, Assignment of Personnel, Development of A Responsive Staff Development Program, School Personnel Acceptance of At-Risk Youth, Parental Involvement, and Community Involvement. Each category is described by five specific practices. A 4-point scale is used to determine the levels of importance and frequency of use.

\section{RELIABILITY AND VALIDITY \\ OF INSTRUMENT}

Reliability and validity are essential to the effectiveness of any data-gathering instrument, and an estimate of the reliability and validity should be made for any newly-developed measure (Gay, 1987; Newman \& Newman, 1977) • 
Reliability is the consistency with which an instrument measures what it is designed to measure. There are several methods of determining the reliability of an instrument: test-retest, parallel forms, split half, Kuder-Richardson formula, and inter-scorer reliability (Best \& Kahn, 1986).

Because the data for this study was obtained through a self-reporting instrument, the test-retest method was the most appropriate test of reliability (Newman \& Newman, 1977). It provides a reliability coefficient which is a function of standard error of measurement.

The questionnaire employed in this study was pilot-tested using 15 randomly-selected principals from the Portland, Oregon metropolitan area. Each principal was contacted by telephone to insure $100 \%$ compliance. A formal request was made to the principals by telephone to complete the survey. Subjects were randomly selected from the oregon School Directory (Oregon Department, 1990) using a table of random numbers. The instruments were mailed with addressed stamped envelopes and all of the instruments were completed and returned within 15 days of mailing. The same subjects were retested 30 days after completion of the initial questionnaire. A Cronbach's (1951) alpha reliability coefficient was computed using the statistical Package for the Social Sciences, version X (Nie, Hull, Jenkins, steinbrenner, \& Bent, 1985). A total scale reliability 
coefficient of .84 was obtained. The results of the pretest/posttest item analysis are listed in Appendix $C$.

Validity is also an important quality to consider when formulating and selecting an evaluation instrument. Newman and Newman (1977) indicate that the "most important characteristic of any test is validity" (p. 49).

Validity can be defined as how well a test measures what it is suppose to measure. There are four types of validity: content, predictive, concurrent, and construct (Best \& Kahn, 1986). Of these four, content validity is the most applicable to the test of the usefulness of the At-Risk Program Profile. Content validity is guided by the question: "Is the substance or content of this measure representative of the content or the universe of the content of the property being measured?" (Kerlinger, 1973, p. 49).

The Critical Principal Practices Profile is a self assessment instrument developed by a team of five elementary school principals and the researcher to provide a thorough analysis of principals' practices which serve at-risk youth. The content validity of the instrument was examined in four ways: identifying administrative practices which prevent at-risk students from becoming dropouts; reviewing the literature to further judge adequacy; translating the practices into a reliable format; and utilizing the subjects of the pilot study as content experts. 
The School Demographic Information section of the instrument was developed by the team after careful review of the literature. Researchers have begun to identify school environments as a factor which significantly contributes to the dropout rate among American youth (Green \& Baker, 1986; Rhodes \& McMillan, 1987; Texas Education Agency, 1989b) . Wehlage and Rutter (1986) suggest that the phenomena of school dropouts is a result of specific student attributes coupled with certain school conditions. McDill, Natriello, and Pallas (1986) identify attributes of schools with high dropout rates. Using these research studies as a baseline of knowledge, the team developed the questions for the first section of the data-collection instrument.

The development of the important practices was based on the fieldwork, experience, and expertise of the team. The researcher used a grounded theory methodology to interview elementary principals representing 12 districts in the Portland, Oregon metropolitan area. Glaser and strauss (1967) first introduced grounded theory methodology in 1967. It is defined as "theory discovered from data systematically obtained and analyzed in sound research" and is particularly useful when no data base exists that adequately answers the questions posed. All respondents queried by the researcher answered the same question: Which principal practices increase the effectiveness of services designed for at-risk youth? From the answers of the principals, several critical 
practices emerged and were identified and classified. The practices were then clarified into carefully worded statements to complete the second section of the questionnaire.

The final draft of the questionnaire was evaluated using the criteria presented by Best and Kahn (1986). The team was confident that the questionnaire in its final form was a reliable and valid instrument.

Before being sent, the questionnaire was scrutinized one last time. Attached to the retest questionnaire, as a part of the pilot study, was an expert judge validity questionnaire asking the following questions: | How many minutes did it take you to complete the survey?; Do you feel the survey is too long?; Are the directions clear and concise?; Do you feel something should be changed?; and Please list any comments or criticisms below. Corrections and additions suggested by the expert judges were considered by the researcher and the following appropriate revisions were completed:

1. The recommendation to change the wording of question 8 from "Percentage of teaching staff/disciplined or reprimanded by you within the last year" to "Percentage of teaching staff receiving less than a satisfactory teaching evaluation by you within the last year."

2. The suggestion to clarify selected practices by adding behavioral language. 
The questionnaire used in this study was the result of a continuing process of survey development based on information from the literature, panel of experts, and responses from the pilot study.

STATISTICAL ANALYSIS

SYSTAT: The System for Statistics (Wilkinson, 1990) was used for the treatment of all data. A number of statistical treatments were performed in analyzing the data. The data collected were subjected to the following statistical analyses:

1. Distribution of school demographic information.

2. Mean scores for the rating of the importance and frequency of use for each principal practice.

3. Analysis of variance (ANOVA) calculated the statistical significance of the association between the principals' practices and the independent variables: percentages of at-risk youth, percentages of students eligible to receive free lunch, numbers of students and percentage of students attending current school for at least one year. The ANOVA can determine the differences between two variables simultaneously, including the individual and interacting effects (Howell, 1982). When the associations reached a statistically significant level, each individual practice used to describe the practice categories was also subjected to an ANOVA. 
4. Pearson's Product-Moment Coefficient of Correlation (Pearson's $r$ ) determined the relationship between the principal practices and the level of success in servicing at-risk youth. Pearson's $r$ is most precise coefficient of correlation and is useful to measure the relationship between two interval variables (Best \& Kahn, 1986) .

BY using an ANOVA, the researcher determined the probability that the difference between sample means was due to chance. The Pearson's r summarized the strength of the association between variables.

A .05 level of significance was used.

LIMITATIONS OF THE STUDY

The following limitations were considered when examining the results of this study.

This study is concerned with data which was collected during the 1991-1992 school year, and the findings only reflect that particular time period.

Data were gathered through survey research. Self-reporting data are inherently subjective in nature and dependent upon the interpretation of the respondents.

The explanatory items used to describe the principal practices were not empirically verified with a factor analysis. 
The population for this study was restricted to those principals employed in the Portland, Oregon metropolitan area. Use of the Portland, oregon metropolitan area provided a sample which may have differed from a similar sample of respondents from another metropolitan area with different demographics. The Portland, Oregon metropolitan area has a much higher percentage of children attending public school than most metropolitan areas in the United states.

\section{SUMMARY}

Subjects used in this study were elementary principals. Data for this study were collected from elementary principals serving students in the Portland, Oregon metropolitan area. The respondents completed the Critical Principal practices Profile, a questionnaire developed by a team of expert practitioners. Descriptive information regarding the respondents was presented. Eight research questions were tested using a variety of statistical methods. 


\section{CHAPTER IV}

\section{FINDINGS}

The purpose of this study is to investigate the relationship of principals' practices to the provisions of services for at-risk youth. Differences in the level of importance and frequency of use of the practices are compared. Percentage of at-risk youth, percentage of students eligible for free lunch, school size, and level of successful service for at-risk youth and their association with principal practices are also investigated.

The findings are presented in two parts. First, the demographic information is presented. Then each of the research questions is restated, the data relevant to the research question are described, and the results are examined.

\section{DEMOGRAPHIC INFORMATION}

Most (83\%) of the respondents were principals of $K-5$ or K-6 elementary schools. Of the 108 principals completing the survey, 29 or $26.9 \%$ worked at small schools (200-399 students), 51 or $47.2 \%$ worked at mid-sized schools (400-599 students), and 28 or $25.9 \%$ worked at large schools (> 600 
students). The school demographics information is exhibited in Table $I$.

TABLE I

SCHOOL DEMOGRAPHICS

\begin{tabular}{lcc}
\hline & $\begin{array}{c}\text { Frequency } \\
(\mathrm{N}=108)\end{array}$ & $\begin{array}{c}\% \text { of } \\
\text { Respondents }\end{array}$ \\
\hline 1. Grade Level Distribution & & \\
Grades: & & 26 \\
K-5 & 28 & 58 \\
K-6 & 63 & 13 \\
PK-5 & 14 & \\
K-4 & 1 & \\
K-8 & 2 & \\
School Size & & 26.9 \\
Subgroup: & & 47.2 \\
Smal1 School & & \\
(200-399 students) & 29 & 25.9 \\
Mid-sized School & & \\
(400-599 students) & 51 & \\
(> $>$ School students) & 28 & \\
\hline
\end{tabular}

The principals responding to the survey served a diverse student population, but the majority of children served were white $(84.98)$. Suspension and expulsion strategies were used sparingly by the respondents. A mean of $2.1 \%$ of the students served were suspended or expelled at least one time during the school year. The students served were enrolled in elementary schools within attendance areas of high schools with a mean dropout rate of $14 \%$. Forty-four 
or $40.7 \%$ of the respondents reported that $26-50 \%$ of the students they served were eligible for free lunch; 34 or $31.5 \%$ reported that $0-25 \%$ of the students served were eligible for free lunch; 22 or $20.4 \%$ reported that 51-75\% of the students served were eligible for free lunch; and 8 or 7.48 reported that $76-100 \%$ of the students served were eligible for free lunch. Responding principals also reported the percentage of the students served who were at-risk of school failure. Sixty-one or $56.5 \%$ of the principals indicated that $1-30 \%$ of the total school population were at-risk; 35 or $32.4 \%$ indicated that $31-60 \%$ of the total school population were at-risk; and 12 or $11.1 \%$ indicated that 61-90\% were at-risk. The principals additionally reported the percentage of students served who attended their current school for at least one year. Fortyeight or 44.48 of the principals reported that 75-86\% of the students attended their current school for at least one year; 32 or 29.68 reported that $87-998$ of the students attended their current school for at least one year; 15 or 13.98 reported that $63-74 \%$ of the students attended their current school for at least one year; and 13 or $12.1 \%$ reported that 50-62\% of the students attended their current school for at least one year. A complete listing of the student demographics are displayed in Tables II and III. 
TABLE II

STUDENT DEMOGRAPHICS I

\begin{tabular}{|c|c|c|c|}
\hline & & Mean \% & sd \% \\
\hline$\overline{1 .}$ & $\begin{array}{l}\text { Ethnicity Percentages } \\
\text { Asian/Pacific Islander } \\
\text { African-American } \\
\text { Hispanic } \\
\text { Native American } \\
\text { White (non-Hispanic) }\end{array}$ & $\begin{array}{r}3.9 \\
6.3 \\
4.2 \\
.8 \\
84.9\end{array}$ & $\begin{array}{r}5.8 \\
9.0 \\
7.5 \\
1.7 \\
15.0\end{array}$ \\
\hline 2 . & $\begin{array}{l}\text { Percentage suspended or } \\
\text { expelled (at least one time } \\
\text { during the year) }\end{array}$ & 2.1 & 2.1 \\
\hline 3. & $\begin{array}{l}\text { District high school dropout } \\
\text { rate }\end{array}$ & 14.3 & 8.9 \\
\hline
\end{tabular}

TABLE III

STUDENT DEMOGRAPHICS II

\begin{tabular}{|c|c|c|c|}
\hline & Subgroup & $\begin{array}{l}\text { Frequency } \\
(\mathrm{N}=108)\end{array}$ & $\begin{array}{c}\quad \frac{\circ}{\zeta} \text { of } \\
\text { Respondents }\end{array}$ \\
\hline 1. & $\begin{array}{l}\text { Percentage of students } \\
\text { eligible for free lunch } \\
0-25 \% \text { eligible } \\
26-50 \% \text { eligible } \\
51-75 \% \text { eligible } \\
76-100 \% \text { eligible }\end{array}$ & $\begin{array}{r}34 \\
44 \\
22 \\
8\end{array}$ & $\begin{array}{r}31.5 \\
40.7 \\
20.4 \\
7.4\end{array}$ \\
\hline 2. & $\begin{array}{l}\text { Percentage of students } \\
\text { of school failure } \\
1-30 \% \text { of students } \\
31-60 \% \text { of students } \\
61-90 \% \text { of students }\end{array}$ & at-risk & $\begin{array}{l}56.5 \\
32.4 \\
11.1\end{array}$ \\
\hline 3. & $\begin{array}{l}\text { Percentage of students } \\
\text { school for at least one } \\
50-62 \% \text { of students } \\
63-74 \% \text { of students } \\
75-86 \% \text { of students } \\
87-99 \% \text { of students }\end{array}$ & $\begin{array}{c}\text { attending current } \\
\text { school year } \\
13 \\
15 \\
48 \\
32\end{array}$ & $\begin{array}{l}12.1 \\
13.9 \\
44.4 \\
29.6\end{array}$ \\
\hline
\end{tabular}


The demographic information also provides interesting information regarding elementary schools located in the metropolitan area of Portland, oregon which possesses characteristics identified by McDill, Natriello, and Pallas (1986) as those associated with the schools that possess a high percentage of early leavers. Twenty-eight or $25.9 \%$ of the schools participating in the study had a student population of more than 600 students. Thirty or $27.8 \%$ of the schools participating in the study had more than $50 \%$ of the student body eligible for free lunch. Eighteen or $26 \%$ of the schools participating in the study had at least $25 \%$ of the student body remaining at their current school for less than one year. Forty-seven or $43.5 \%$ of the schools participating in the study had more than $30 \%$ of the student body at-risk of school of failure.

The respondents reported that white teachers comprised 93.7\% of their certified staffs. African-American teachers registered the second largest percentage of certified teaching staffs at $4 \%$. One and eight tenths percent of the teachers that were supervised by the respondents received less than a satisfactory evaluation. The complete teacher demographic information is displayed in Table IV. 
TABLE IV

TEACHER DEMOGRAPHICS

\begin{tabular}{lrr}
\hline & Mean & sd \\
\hline Number of Teachers & 24.4 & 6.6 \\
Ethnicity Percentages: & & \\
Asian/Pacific Islander & $.7 \%$ & $2.4 \%$ \\
$\quad \begin{array}{l}\text { African-American } \\
\text { Hispanic }\end{array}$ & $4.0 \%$ & $9.7 \%$ \\
$\quad$ Native American & $1.2 \%$ & $2.6 \%$ \\
White (non-Hispanic) & $.3 \%$ & $1.9 \%$ \\
Percentage receiving less than & $93.7 \%$ & \\
a satisfactory evaluation within & & \\
the year & $1.8 \%$ & $2.1 \%$ \\
\hline
\end{tabular}

Eighty-three percent of the reporting principals felt that their schools were serving at-risk students very successfully or somewhat successfully. The ratings by the principals of the provision of service for at-risk youth are displayed in Table $V$.

\section{TABLE V}

RATING OF PROVISION OF SERVICE

FOR AT-RISK. YOUTH

\section{Level}

Frequency

$(\mathrm{N}=108)$

$\%$

Very Unsuccessfully Somewhat Unsuccessfully Somewhat Successfully Very Successfully

$\begin{array}{rr}0 & 0 \\ 18 & 17 \\ 70 & 65 \\ 20 & 18\end{array}$

0 18 
ANALYSIS OF RESEARCH QUESTIONS

\section{Research Question \#1}

What practices do principals perceive as important in serving at-risk youth in elementary schools?

A mean score was calculated for the respondents' ratings of the importance of seven principal practices intended to serve at-risk youth. Each of the seven practices contained five explanatory items. Each of the items was rated from very unimportant (1) to very important (4). The mean of the principals' ratings of the importance of each practice $(N=108)$ was calculated. Selection of Service Delivery Patterns emerged as the most important practice $(\underline{M}=3.65)$ for serving at-risk youth. Ranking a close second was A Responsive staff Development Program $(\underline{M}=3.60)$. School Personnel Acceptance $(\underline{M}=3.58)$ ranked third, Assignment of Personnel ( $M=3.57$ ) ranked fourth, and Principal Influences on District Level Support and Parental Involvement $(\underline{M}=3.55)$ each ranked 5.5. According to the respondents, the least important practice was community Involvement $(\underline{M}=3.16)$. Each of the practices were rated as "important" by the principal.

A complete listing of the mean and rank of the importance of each principal practice is exhibited in Table VI. 
TABLE VI

MEAN SCORES AND RANK OF IMPORTANCE OF PRINCIPAL PRACTICES

\begin{tabular}{|c|c|c|c|}
\hline Practice & Rank & Mean & sd \\
\hline $\begin{array}{l}\text { Selection of Service } \\
\text { Delivery Patterns }\end{array}$ & 1 & 3.65 & .339 \\
\hline $\begin{array}{l}\text { A Responsible Staff } \\
\text { Development Program }\end{array}$ & 2 & 3.60 & .367 \\
\hline $\begin{array}{l}\text { School Personnel } \\
\text { Acceptance }\end{array}$ & 3 & 3.58 & .357 \\
\hline Assignment of Personnel & 4 & 3.57 & .335 \\
\hline $\begin{array}{l}\text { Principal Influences on } \\
\text { District Level Support }\end{array}$ & 5.5 & 3.55 & .414 \\
\hline Parental Involvement & 5.5 & 3.55 & .394 \\
\hline Community Involvement & 7 & 3.16 & .578 \\
\hline
\end{tabular}

Research Question \#2

How frequently are principal practices serving at-risk youth in use in elementary schools?

A mean score was calculated for the respondents' ratings of the frequency of use of seven principal practices intended to serve at-risk youth. Each of the seven practices contained five explanatory items. Each of the items was rated from very infrequent use (1) to very frequent use (4). The mean of the principals' ratings of the frequency of use of each practice $(\mathrm{N}=108)$ was calculated. Selection of Service Delivery Patterns also 
emerged as the most frequently used practice $(\underline{M}=3.21)$ for serving at-risk youth. Ranking second was Parental Involvement $(\underline{M}=3.16)$. School Personnel Acceptance $(\underline{M}=3.13)$ ranked third, $\mathrm{A}$ Responsive staff Development Program $(\underline{M}=3.07)$ ranked fourth, Principal Influences on District Level Support $(\underline{M}=2.79)$ ranked fifth and Assignment of Personnel $(\underline{M}=2.78)$ ranked sixth. The least used practice, Community Involvement $(\underline{M}=2.49)$, was also ranked as the least important practice.

A complete listing of the mean and rank of the frequency of use of each practice is exhibited in Table VII.

TABLE VII

MEAN SCORES AND RANK OF FREQUENCY OF USE OF PRINCIPAL PRACTICES

\begin{tabular}{lccc}
\hline Practice & Rank & Mean & sd \\
\hline $\begin{array}{l}\text { Selection of Service } \\
\text { Delivery Patterns }\end{array}$ & 1 & 3.21 & .597 \\
$\begin{array}{l}\text { Parental Involvement } \\
\text { School Personnel }\end{array}$ & 2 & 3.16 & .445 \\
$\begin{array}{l}\text { Acceptance } \\
\begin{array}{l}\text { A Responsive Staff } \\
\text { Development Program }\end{array}\end{array}$ & 3 & 3.13 & .528 \\
$\begin{array}{l}\text { Principal Influences on } \\
\text { District Level Support }\end{array}$ & 4 & 3.07 & .519 \\
Assignment of Personnel & 5 & 2.79 & .634 \\
Community Involvement & 6 & 2.78 & .538 \\
\end{tabular}


Research Question \#3

What are the differences between the principals' ratings of the importance and frequency of use of practices designed to serve at-risk youth?

Using a 4-point scale, principals indicated the importance and frequency of use of principal practices for the provision of service for at-risk youth. The ratings of the importance and the frequency of use of principal practices are displayed concurrently in Table VIII. The practices, ranks of the importance and frequency of use ratings, and mean scores are reported.

TABLE VIII

MEAN SCORES AND RANK OF IMPORTANCE AND FREQUENCY OF USE OF PRINCIPAL PRACTICES

\begin{tabular}{|c|c|c|c|c|c|c|}
\hline \multirow[b]{2}{*}{ Practice } & \multicolumn{3}{|c|}{ IMPORTANCE } & \multicolumn{2}{|c|}{ FREQUENCY OF } & \multirow{2}{*}{$\begin{array}{l}\text { USE } \\
\text { sd }\end{array}$} \\
\hline & Rank & Mean & sd & Rank & Mean & \\
\hline $\begin{array}{l}\text { Selection of Service } \\
\text { Delivery Patterns }\end{array}$ & 1 & 3.65 & .339 & 1 & 3.21 & .597 \\
\hline $\begin{array}{l}\text { A Responsible staff } \\
\text { Development Program }\end{array}$ & 2 & 3.60 & .367 & 4 & 3.07 & .519 \\
\hline $\begin{array}{l}\text { School Personnel } \\
\text { Acceptance }\end{array}$ & 3 & 3.58 & .357 & 3 & 3.13 & .528 \\
\hline Assignment of Personnel & 4 & 3.57 & .335 & 6 & 2.78 & .538 \\
\hline $\begin{array}{l}\text { Principal Influences on } \\
\text { District Level Support }\end{array}$ & 5.5 & 3.55 & .414 & 5 & 2.79 & .634 \\
\hline Parental Involvement & 5.5 & 3.55 & .394 & 2 & 3.16 & .445 \\
\hline Community Involvement & 7 & 3.16 & .578 & 7 & 2.49 & .764 \\
\hline
\end{tabular}


The mean scores for the principal practice selection of Service Delivery Patterns were 3.65 and 3.21 for the ratings of the importance and frequency of use respectively. The standard deviations were .339 and .597.

The mean scores for the principal practice $A$ Responsive Staff Development Program were 3.60 and 3.07 for the ratings of the importance and frequency of use respectively. The standard deviations were .367 and .519 .

The mean scores for the principal practice School Personnel Acceptance were 3.58 and 3.13 for the ratings of the importance and frequency of use respectively. The standard deviations were .357 and .528 .

The mean scores for the principal practice Assignment of Personnel were 3.57 and 2.78 for the ratings of the importance and frequency of use respectively. The standard deviations were .335 and .528 .

The mean scores for the principal practice Principal Influences on District Level Support were 3.55 and 2.79 for the ratings of the importance and frequency of use respectively. The standard deviations were .414 and .634.

The mean scores for the principal practice Parental Involvement were 3.55 and 3.16 for the ratings of the importance and frequency of use respectively. The standard deviations were .394 and .445 .

The mean scores for the principal practice community Involvement were 3.65 and 3.21 for the ratings of the 
importance and frequency of use respectively. The standard deviations were .578 and .764 .

The principals reported that selection of service Delivery Patterns was the most important and frequently used practice. To elaborate on the definition of the practice, the five explanatory items are listed in Table IX. The items, importance mean scores, frequency of use mean scores, and rankings within the practice are presented.

TABLE IX

SELECTION OF SERVICE DELIVERY PATTERNS PRACTICE:

MEAN SCORES AND RANK OF IMPORTANCE AND FREQUENCY OF USE OF SPECIFIC ITEMS

\begin{tabular}{|c|c|c|c|c|c|c|}
\hline \multirow[b]{2}{*}{ Item } & \multicolumn{3}{|c|}{ IMPORTANCE } & \multicolumn{2}{|c|}{ FREQUENCY OF } & \multirow{2}{*}{$\begin{array}{l}\text { USE } \\
\text { sd }\end{array}$} \\
\hline & Rank & Mean & sd & Rank & Mean & \\
\hline \multicolumn{7}{|l|}{ Identifying at-risk } \\
\hline \multirow{2}{*}{\multicolumn{7}{|c|}{ Monitoring student }} \\
\hline & & & & & & \\
\hline performance & 2 & 3.75 & .495 & 2 & 3.25 & .799 \\
\hline \multicolumn{7}{|l|}{ Implementing retention } \\
\hline alternatives & 3 & 3.58 & .598 & 4 & 3.08 & .799 \\
\hline \multicolumn{7}{|l|}{$\begin{array}{l}\text { Requiring the } \\
\text { modification of }\end{array}$} \\
\hline curriculum & 4.5 & 3.56 & .553 & 5 & 3.03 & .767 \\
\hline \multicolumn{7}{|l|}{$\begin{array}{l}\text { Identifying suspension } \\
\text { and expulsion }\end{array}$} \\
\hline alternatives & 4.5 & 3.56 & .646 & 3 & 3.11 & .910 \\
\hline
\end{tabular}

An elaboration of the highest mean rankings of the explanatory item for the importance and frequency of use of 
each principal practice also assists in the further explanation of the data. This information is exhibited in Table X.

TABLE X

RANK, MEAN SCORES, AND STANDARD DEVIATION OF HIGHEST

PRINCIPALS' RATINGS FOR IMPORTANCE AND FREQUENCY

OF USE OF EXPLANATORY ITEMS FOR

EACH PRINCIPAL PRACTICE

\begin{tabular}{|c|c|c|c|c|c|c|}
\hline \multirow[b]{2}{*}{ Practice } & \multicolumn{3}{|c|}{ IMPORTANCE } & \multicolumn{2}{|c|}{ FREQUENCY OF } & \multirow{2}{*}{$\begin{array}{l}\text { USE } \\
\text { sd }\end{array}$} \\
\hline & Rank & Mean & sd & Rank & Mean & \\
\hline $\begin{array}{l}\text { Practice 1: Principal } \\
\text { Influences on District } \\
\text { Level Support } \\
\text { cultivating district } \\
\text { administrative support } \\
\text { for building level } \\
\text { orograms }\end{array}$ & 1 & 3.69 & 571 & 1 & 3.06 & 818 \\
\hline $\begin{array}{l}\text { Practice } 2: \text { Selection of } \\
\text { Service Delivery Patterns } \\
\text { identifying at-risk } \\
\text { students }\end{array}$ & 1 & 3.80 & .398 & 1 & 3.58 & .685 \\
\hline $\begin{array}{l}\text { Practice } 3 \text { : Assignment } \\
\text { of Personnel } \\
\text { hiring staff who } \\
\text { establishes rapport } \\
\text { and develops } \\
\text { relationships with } \\
\text { students }\end{array}$ & 1 & 3.81 & .520 & 1 & 3.36 & .952 \\
\hline $\begin{array}{l}\text { Practice 4: A Responsive } \\
\text { Staff Development Program } \\
\text { providing annual } \\
\text { training for new staff }\end{array}$ & 1 & 3.89 & .398 & 1 & 3.42 & .685 \\
\hline $\begin{array}{l}\text { Practice 5: School } \\
\text { Personnel Acceptance } \\
\text { encouraging teaching } \\
\text { to various learning } \\
\text { styles }\end{array}$ & 1 & 3.75 & .495 & 1 & 3.42 & .685 \\
\hline
\end{tabular}


TABLE X

RANK, MEAN SCORES, AND STANDARD DEVIATION OF HIGHEST

PRINCIPALS' RATINGS FOR IMPORTANCE AND FREQUENCY

OF USE OF EXPLANATORY ITEMS FOR

EACH PRINCIPAL PRACTICE

(Continued)

\begin{tabular}{|c|c|c|c|c|c|c|}
\hline \multirow[b]{2}{*}{ Practice } & \multicolumn{3}{|c|}{ IMPORTANCE } & \multicolumn{2}{|c|}{ FREQUENCY OF } & \multirow{2}{*}{$\begin{array}{l}\text { USE } \\
\text { sd }\end{array}$} \\
\hline & Rank & Mean & sd & Rank & Mean & \\
\hline \multirow{2}{*}{$\begin{array}{l}\text { Practice } 6: \text { Parental } \\
\text { Involvement } \\
\text { notifying parents of } \\
\text { nonattendance. }\end{array}$} & & & & & & \\
\hline & 1 & 3.80 & .463 & 1 & 3.55 & .765 \\
\hline$\frac{\text { Practice } 7:}{\text { Involvement }}$ Community & & & & & & \\
\hline $\begin{array}{l}\text { providing a newsletter } \\
\text { for community members }\end{array}$ & 1 & 3.25 & .866 & 1 & 2.97 & 1.150 \\
\hline
\end{tabular}

A presentation of the ranks, mean scores, and standard deviations of the principals' ratings for the importance and frequency of use of each explanatory item, listed by practice, is exhibited in Appendix D. The mean scores and rank of the importance and frequency of use of each explanatory item, listed by item, is displayed in Appendix E.

Research Question \#4

What principal practices designed to serve at-risk youth are associated with elementary school size?

The principal practices and school size were compared using an ANOVA. The principal practices were the dependent variables and the school size was the independent variable. 
A .05 level of significance was used. Using a 4-point scale, the principals indicated the levels of importance and frequency of use of each practice.

Each principal also reported the number of students enrolled at their school. To formulate the subgroups of the independent variable, the reported school populations were collapsed into three sections: schools enrolling from 200 to 399 students or "small schools" ( $=29)$, schools enrolling from 400 to 599 students or "mid-sized schools" $(N=51)$, and schools enrolling more than 600 students or "large schools" $(\mathrm{N}=28)$. The independent variable was collapsed into the three subgroups used by Portland Public Schools to classify elementary schools for the purpose of resource distribution.

Differences reaching a significant level were found between school size and the importance and frequency of use ratings of selected principal practices. An analysis of variance indicated a significant difference $(p<.05)$ related to school size in the ratings for the following principal practices: importance of selection of service Delivery Patterns; the frequency of use of selection of Service Delivery Patterns; importance of Assignment of Personnel; and frequency of use of School Personnel Acceptance. Even though significant differences were found, the means of ratings for the principal practices within each subgroup do not demonstrate a clear explanation of the 
variance. No specific subgroup trend was observed upon examination of the significant differences.

The complete results are displayed in Table XI. The mean scores for each collapsed school size grouping by practice and the significance level (ANOVA) are reported.

TABLE XI

ASSOCIATION OF PRINCIPAL PRACTICES

WITH SCHOOL SIZE

\begin{tabular}{|c|c|c|c|c|}
\hline Practice & $\begin{array}{l}\text { INCIPAL } \\
\text { small } \\
\text { school } \\
(\mathrm{N}=29)\end{array}$ & $\begin{array}{l}\text { PRACTICES } \\
\text { mid-size } \\
\text { school } \\
(\mathrm{N}=51)\end{array}$ & $\begin{array}{l}\text { MEAN SCORES } \\
\text { large } \\
\text { school } \\
(n=28)\end{array}$ & $\begin{array}{c}\text { SIG } \\
\text { LEVEL } \\
\text { (ANOVA) }\end{array}$ \\
\hline $\begin{array}{l}\text { Principal Influences on } \\
\text { District Level Support } \\
\text { Importance of Practice } \\
\text { Frequency of Use }\end{array}$ & $\begin{array}{l}3.50 \\
2.87\end{array}$ & $\begin{array}{l}3.62 \\
2.83\end{array}$ & $\begin{array}{l}3.46 \\
2.66\end{array}$ & $\begin{array}{l}\text { N.S. } \\
\text { N.S. }\end{array}$ \\
\hline $\begin{array}{l}\text { Selection of Service } \\
\text { Delivery Patterns } \\
\text { Importance of Practice } \\
\text { Frequency of Use }\end{array}$ & $\begin{array}{l}3.49 \\
3.03\end{array}$ & $\begin{array}{l}3.74 \\
3.37\end{array}$ & $\begin{array}{l}3.64 \\
3.11\end{array}$ & $\begin{array}{l}\mathrm{p}<.05 \\
\mathrm{p}<.05\end{array}$ \\
\hline $\begin{array}{l}\text { Assignment of Personnel } \\
\text { Importance of Practice } \\
\text { Frequency of Use }\end{array}$ & $\begin{array}{l}3.49 \\
2.79\end{array}$ & $\begin{array}{l}3.64 \\
2.87\end{array}$ & $\begin{array}{l}3.59 \\
2.64\end{array}$ & $\begin{array}{l}\mathrm{p}<.05 \\
\text { N.S. }\end{array}$ \\
\hline $\begin{array}{l}\text { A Responsive Staff } \\
\text { Development Program } \\
\text { Importance of Practice } \\
\text { Frequency of Use }\end{array}$ & $\begin{array}{l}3.53 \\
3.04\end{array}$ & $\begin{array}{l}3.66 \\
3.17\end{array}$ & $\begin{array}{l}3.56 \\
2.93\end{array}$ & $\begin{array}{l}\text { N.S. } \\
\text { N.S. }\end{array}$ \\
\hline $\begin{array}{l}\text { School Personnel Acceptar } \\
\text { Importance of Practice } \\
\text { Frequency of Use }\end{array}$ & $\begin{array}{l}3.59 \\
3.14\end{array}$ & $\begin{array}{l}3.60 \\
3.23\end{array}$ & $\begin{array}{l}3.53 \\
2.93\end{array}$ & $\begin{array}{l}\text { N.S. } \\
\text { p<.05 }\end{array}$ \\
\hline $\begin{array}{l}\text { Parental Involvement } \\
\text { Importance of Practice } \\
\text { Frequency of Use }\end{array}$ & $\begin{array}{l}3.51 \\
3.23\end{array}$ & $\begin{array}{l}3.59 \\
3.21\end{array}$ & $\begin{array}{l}3.51 \\
2.99\end{array}$ & N.S. \\
\hline $\begin{array}{l}\text { Community Involvement } \\
\text { Importance of Practice } \\
\text { Frequency of Use }\end{array}$ & $\begin{array}{l}3.26 \\
2.59\end{array}$ & $\begin{array}{l}3.08 \\
2.47\end{array}$ & $\begin{array}{l}3.21 \\
2.44\end{array}$ & $\begin{array}{l}\text { N.S. } \\
\text { N.S. }\end{array}$ \\
\hline
\end{tabular}




\section{Research Question \#\#}

What principal practices designed to serve at-risk youth are associated with percentages of elementary students eligible to receive free lunch?

The principal practices and levels of students eligible to receive free lunch were compared using an ANOVA. The principal practices were the dependent variables and the percentages of students eligible to receive free lunch was the independent variable. A .05 level of significance was used.

Each principal also reported the percentage of students eligible for free lunch. To formulate the subgroups of the independent variable, the reported free lunch percentages were collapsed into four sections: 0-25\% $(\mathrm{N}=34), 26-50 \%(\mathrm{~N}=44), 51-75 \%(\mathrm{~N}=22)$, and 76-100\% $(\mathrm{N}=8)$.

The independent variable was collapsed into these particular sections because the state of Oregon uses these categories when determining the socioeconomic status of elementary schools.

Differences reaching a significant level ( $p<.05)$ were found between groups based on the levels of students eligible for free lunch and the importance and the frequency of use ratings of two principal practices. An analysis of variance indicated a significant difference between the percentage of students eligible for free lunch and the 
ratings for the frequency of use of School Personnel

Acceptance and Parental Involvement.

The complete results are displayed in Table XII. The mean scores for each percentage of students eligible for free lunch grouping by practice and the significance level (ANOVA) are reported. By observing the means of the principal practices for each subgroup, one can visually discern that no pattern or trend within the subgroups is apparent.

TABLE XII

ASSOCIATION OF PRINCIPAL PRACTICES WITH PERCENTAGE OF STUDENTS ELIGIBLE FOR FREE LUNCH

\begin{tabular}{|c|c|c|c|c|c|}
\hline Practice & \multicolumn{4}{|c|}{$\begin{array}{l}\text { RINCIPAL PRACTICES MEAN SCORES } \\
\text { (\% Eligible for Free Lunch) }\end{array}$} & $\begin{array}{c}\text { SIG } \\
\text { LEVEI } \\
\text { (ANOVA) }\end{array}$ \\
\hline \multicolumn{6}{|l|}{$\begin{array}{l}\text { Principal Influences on } \\
\text { District Level Support }\end{array}$} \\
\hline $\begin{array}{l}\text { Importance of Practice } \\
\text { Frequency of Use }\end{array}$ & $\begin{array}{l}3.50 \\
2.78\end{array}$ & $\begin{array}{l}3.51 \\
2.64\end{array}$ & $\begin{array}{l}3.58 \\
3.01\end{array}$ & $\begin{array}{l}3.82 \\
3.12\end{array}$ & $\begin{array}{l}\text { N.S. } \\
\text { N.S. }\end{array}$ \\
\hline \multicolumn{6}{|l|}{$\begin{array}{l}\text { Selection of Service } \\
\text { Delivery Patterns }\end{array}$} \\
\hline $\begin{array}{l}\text { Importance of Practice } \\
\text { Frequency of Use }\end{array}$ & $\begin{array}{l}3.68 \\
2.28\end{array}$ & $\begin{array}{l}3.57 \\
3.06\end{array}$ & $\begin{array}{l}3.67 \\
3.30\end{array}$ & $\begin{array}{l}3.85 \\
3.50\end{array}$ & $\begin{array}{l}\text { N.S. } \\
\text { N.S. }\end{array}$ \\
\hline $\begin{array}{l}\text { Assignment of Personnel } \\
\text { Importance of Practice } \\
\text { Frequency of Use }\end{array}$ & $\begin{array}{l}3.61 \\
2.81\end{array}$ & $\begin{array}{l}3.54 \\
2.78\end{array}$ & $\begin{array}{l}3.61 \\
2.82\end{array}$ & $\begin{array}{l}3.47 \\
2.70\end{array}$ & $\begin{array}{l}\text { N.S. } \\
\text { N.S. }\end{array}$ \\
\hline \multicolumn{6}{|l|}{$\begin{array}{l}\text { A Responsive Staff } \\
\text { Development Program }\end{array}$} \\
\hline $\begin{array}{l}\text { Importance of Practice } \\
\text { Frequency of Use }\end{array}$ & $\begin{array}{l}3.68 \\
3.15\end{array}$ & $\begin{array}{l}3.54 \\
2.96\end{array}$ & $\begin{array}{l}3.62 \\
3.18\end{array}$ & $\begin{array}{l}3.55 \\
3.10\end{array}$ & $\begin{array}{l}\text { N.S. } \\
\text { N.S. }\end{array}$ \\
\hline
\end{tabular}


TABLE XII

ASSOCIATION OF PRINCIPAL PRACTICES WITH PERCENTAGE

OF STUDENTS ELIGIBLE FOR FREE LUNCH

(Continued)

\begin{tabular}{|c|c|c|c|c|c|}
\hline Practice & \multicolumn{4}{|c|}{$\begin{array}{l}\text { PRINCIPAL PRACTICES MEAN SCORES } \\
\text { (\% Eligible for Free Lunch) }\end{array}$} & $\begin{array}{c}\text { SIG } \\
\text { LEVEL } \\
\text { (ANOVA) }\end{array}$ \\
\hline \multicolumn{6}{|l|}{ School Personnel } \\
\hline $\begin{array}{l}\text { Importance of Practice } \\
\text { Frequency of Use }\end{array}$ & $\begin{array}{l}3.64 \\
3.32\end{array}$ & $\begin{array}{l}3.52 \\
3.30\end{array}$ & $\begin{array}{l}3 \cdot 56 \\
3.10\end{array}$ & $\begin{array}{l}3.67 \\
2.95\end{array}$ & $\begin{array}{l}\text { N.S. } \\
\mathrm{p}<.01\end{array}$ \\
\hline $\begin{array}{l}\text { Parental Involvement } \\
\text { Importance of Practice } \\
\text { Frequency of Use }\end{array}$ & $\begin{array}{l}3.64 \\
3.31\end{array}$ & $\begin{array}{l}3.46 \\
2.99\end{array}$ & $\begin{array}{l}3.57 \\
3.16\end{array}$ & $\begin{array}{l}3.58 \\
3.35\end{array}$ & $\begin{array}{l}\text { N.S. } \\
\mathrm{p}<.01\end{array}$ \\
\hline $\begin{array}{l}\text { Community Involvement } \\
\text { Importance of Practice } \\
\text { Frequency of Use }\end{array}$ & $\begin{array}{l}3.24 \\
2.64\end{array}$ & $\begin{array}{l}3.08 \\
2.41\end{array}$ & $\begin{array}{l}3.22 \\
2.52\end{array}$ & $\begin{array}{l}3.12 \\
2.25\end{array}$ & $\begin{array}{l}\text { N.S. } \\
\text { N.S. }\end{array}$ \\
\hline
\end{tabular}

Research Question \#6

What principal practices designed to serve at-risk

youth are associated with percentages of at-risk youth

attending elementary schools?

The principal practices and percentages of at-risk

youth attending elementary schools were compared using an

ANOVA. The principal practices were the dependent variables and the percentages of students eligible to receive free lunch was the independent variable. A.05। level of significance was used.

Each principal also reported the percentage of at-risk youth attending their school. To formulate the subgroups of 
the dependent variable, the reported at-risk youth percentages were collapsed into three sections: 1-30\% $(\mathrm{N}=61), 31-60 \%(\mathrm{~N}=35), 61-90 \%(\mathrm{~N}=12)$. The researcher formulated these sections based on the observations of schools possessing a variety of percentages of at-risk youth and determining that dividing by thirds would be appropriate for the study.

Differences reaching a significant level were found between the percentages of at-risk students and the importance and frequency of use ratings of three principal practices. An analysis of variance indicated a significant difference $(p<.05)$ between the groups based on the percentage of students at-risk of school failure and the ratings for the following principal practices: importance of Principal Influence on District Level Support, frequency of use of Principal Influences on District Level Support, importance of School Personnel Acceptance, and frequency of use of Community Involvement. Although 7 of the 14 variables showed a significant difference, a close scrutiny of the means for each practice by at-risk category reveals no discernable trend.

The complete results are displayed in Table XIII. The mean scores for each percentage of students eligible for free lunch grouping by practice and the significance level (ANOVA) are reported. 
TABLE XIII

ASSOCIATION OF PRINCIPAL PRACTICES WITH

PERCENTAGE OF AT-RISK YOUTH

\begin{tabular}{|c|c|c|c|c|}
\hline Practice & $\begin{array}{r}\text { PRINCIPAL } \\
\left(\begin{array}{l}\% \\
1-30 \\
(\mathrm{~N}=61)\end{array}\right.\end{array}$ & $\begin{array}{c}\text { PRACTICES } \\
\text { students } \\
31-60 \\
(N=35)\end{array}$ & $\begin{array}{l}\text { MEAN SCORES } \\
\text { At-Risk) } \\
61-90 \\
(n=12)\end{array}$ & $\begin{array}{c}\text { SIG } \\
\text { LEVEL } \\
\text { (ANOVA) }\end{array}$ \\
\hline
\end{tabular}

Principal Influences on

District Level support

$\begin{array}{lllll}\text { Importance of Practice } & 3.88 & 3.45 & 3.54 & \mathrm{p}<.05 \\ \text { Frequency of Use } & 2.82 & 2.50 & 3.48 & \mathrm{p}<.0001\end{array}$

Selection of Service

Delivery Patterns

$\begin{array}{lllll}\text { Importance of Practice } & 3.66 & 3.92 & 3.55 & \mathrm{p}<.01 \\ \text { Frequency of Use } & 3.21 & 3.09 & 3.62 & \mathrm{p}<.05\end{array}$

Assignment of Personnel

$\begin{array}{lllll}\text { Importance of Practice } & 3.57 & 3.61 & 3.62 & \text { N.S. } \\ \text { Frequency of Use } & 2.88 & 2.62 & 2.76 & \text { N.S. }\end{array}$

A Responsive Staff

Development Program

$\begin{array}{lllll}\text { Importance of Practice } & 3.57 & 3.67 & 3.60 & \text { N.S. } \\ \text { Frequency of Use } & 3.09 & 3.01 & 3.18 & \text { N.S. }\end{array}$

School Personnel

Acceptance

$\begin{array}{lllll}\text { Importance of Practice } & 3.59 & 3.57 & 3.46 & \text { N.S. } \\ \text { Frequency of Use } & 3.20 & 3.02 & 3.02 & \text { p }<.05\end{array}$

Parental Involvement

$\begin{array}{lllll}\text { Importance of Practice } & 3.55 & 3.58 & 3.44 & \text { N.S. } \\ \text { Frequency of Use } & 3.16 & 3.14 & 3.20 & \text { N.S. }\end{array}$

Community Involvement

$\begin{array}{lllll}\text { Importance of Practice } & 3.15 & 3.32 & 2.64 & p<.01 \\ \text { Frequency of Use } & 2.44 & 2.78 & 1.90 & p<.01\end{array}$


Research Question \#7

What principal practices designed to serve at-risk youth are associated with the percentages of students attending their current school for at least one year?

The principal practices and levels of students attending their current school for at least one year were compared using an ANOVA. The principal practices were the dependent variables and the percentages of students eligible to receive free lunch was the independent variable. To formulate the subgroups of the independent variable, the reported student attendance percentages were collapsed into four sections: $50-62 \%(N=13), 63-74 \%(N=15), 75-86 \%$ $(N=48), 87-998(N=32)$. Since the literature and the practitioners both emphasize the impact of the percentage of students remaining at a school for one year on the students and school programs, the researcher categorized the percentages into the smallest sections possible to discover possible effects on the principal practices without compromising accuracy because of low representation with each category.

Differences reaching a significant level were found between the groups based on the percentage of student attendance and the importance and frequency of use ratings of selected principal practices. An analysis of variance indicated a significant difference $(p<.05)$ between the groups based on the percentage of students at-risk and the 
groups based on the percentage of students at-risk and the ratings of the following principal practices: frequency of use of Principal Influences on District Level Support, importance of Selection of Service Delivery Patterns, importance of Assignment of Personnel, frequency of use of Assignment of Personnel, importance of A Responsive staff Development Program, frequency of use of School Personnel Acceptance, importance of Parental Involvement, and frequency of use of Parental Involvement. The ANOVA indicated a significant difference between the dependent variables and the percentage of students attending respondents' school for at least one year on eight variables; however, as is true in all other ANOVA results, no trends or patterns are discernable.

The complete results are displayed in Table XIV. The mean scores for the groupings of the percentage of students attending their school for at least one year by practice and the significance level (ANOVA) are reported. 
TABLE XIV

ASSOCIATION OF PRINCIPAL PRACTICES WITH PERCENTAGE
OF STUDENTS ATTENDING RESPONDENT'S SCHOOL FOR AT LEAST ONE YEAR

\begin{tabular}{|c|c|c|c|c|c|}
\hline Practice & $\begin{array}{r}\text { PRINCIP } \\
(\% \text { St } \\
50-62 \\
(N=13)\end{array}$ & $\begin{array}{l}\text { I PRACTI } \\
\text { :udents } \\
\text { Least or } \\
63-79 \\
(N=15)\end{array}$ & $\begin{array}{l}\text { CES MEAN } \\
\text { ttending } \\
\text { e Year }) \\
75-86 \\
(N=48)\end{array}$ & $\begin{array}{l}\text { N SCORES } \\
\text { g at } \\
\\
\begin{array}{l}87-99 \\
(\mathrm{~N}=32)\end{array}\end{array}$ & $\begin{array}{l}\text { SIG } \\
\text { LEVEI } \\
\text { (ANOVA) } \\
\end{array}$ \\
\hline \multicolumn{6}{|l|}{$\begin{array}{l}\text { Principal Influences } \\
\text { on District Level } \\
\text { Support }\end{array}$} \\
\hline $\begin{array}{l}\text { Importance of Practice } \\
\text { Frequency of Use }\end{array}$ & $\begin{array}{l}3.63 \\
2.89\end{array}$ & $\begin{array}{l}3.43 \\
2.52\end{array}$ & $\begin{array}{l}3.59 \\
2.69\end{array}$ & $\begin{array}{l}3.51 \\
3.03\end{array}$ & $\begin{array}{l}\text { N.S. } \\
\mathrm{p}<.05\end{array}$ \\
\hline \multicolumn{6}{|l|}{$\begin{array}{l}\text { Selection of Service } \\
\text { Delivery Patterns }\end{array}$} \\
\hline $\begin{array}{l}\text { Importance of Practice } \\
\text { Frequency of Use }\end{array}$ & $\begin{array}{l}3.68 \\
2.26\end{array}$ & $\begin{array}{l}3.74 \\
3.13\end{array}$ & $\begin{array}{l}3.78 \\
3.28\end{array}$ & $\begin{array}{l}3.41 \\
3.12\end{array}$ & $\begin{array}{l}\mathrm{p}<.0001 \\
\text { N.S. }\end{array}$ \\
\hline $\begin{array}{l}\text { Assignment of Personnel } \\
\text { Importance of Practice } \\
\text { Frequency of Use }\end{array}$ & $\begin{array}{l}3.49 \\
2.61\end{array}$ & $\begin{array}{l}3.67 \\
2.71\end{array}$ & $\begin{array}{l}3.65 \\
2.61\end{array}$ & $\begin{array}{l}3.45 \\
3.16\end{array}$ & $\begin{array}{l}\mathrm{p}<.05 \\
\mathrm{p}<.0001\end{array}$ \\
\hline \multicolumn{6}{|l|}{ A Responsive staff } \\
\hline $\begin{array}{l}\text { Importance of Practice } \\
\text { Frequency of Use }\end{array}$ & $\begin{array}{l}3.66 \\
3.18\end{array}$ & $\begin{array}{l}3.67 \\
2.89\end{array}$ & $\begin{array}{l}3.70 \\
3.05\end{array}$ & $\begin{array}{l}3.39 \\
3.15\end{array}$ & $\begin{array}{l}p<.01 \\
\text { N.S. }\end{array}$ \\
\hline \multicolumn{6}{|l|}{$\begin{array}{l}\text { School Personnel } \\
\text { Acceptance }\end{array}$} \\
\hline $\begin{array}{l}\text { Importance of Practice } \\
\text { Frequency of Use }\end{array}$ & $\begin{array}{r}3.60 \\
2.89\end{array}$ & $\begin{array}{l}3.61 \\
2.92\end{array}$ & $\begin{array}{l}3.60 \\
3.27\end{array}$ & $\begin{array}{l}3.52 \\
3.09\end{array}$ & $\begin{array}{l}\text { N.S. } \\
\mathrm{p}<.05\end{array}$ \\
\hline $\begin{array}{l}\text { Parental Involvement } \\
\text { Importance of Practice } \\
\text { Frequency of Use }\end{array}$ & $\begin{array}{r}3.81 \\
3.26\end{array}$ & $\begin{array}{l}3.59 \\
2.86\end{array}$ & $\begin{array}{l}3.55 \\
3.28\end{array}$ & $\begin{array}{l}3.42 \\
3.05\end{array}$ & $\begin{array}{l}p<.05 \\
p<.01\end{array}$ \\
\hline $\begin{array}{l}\text { Community Involvement } \\
\text { Importance of Practice } \\
\text { Frequency of Use }\end{array}$ & $\begin{array}{l}3.03 \\
2.40\end{array}$ & $\begin{array}{l}3.09 \\
2.30\end{array}$ & $\begin{array}{l}3.23 \\
2.51\end{array}$ & $\begin{array}{l}3.14 \\
2.59\end{array}$ & $\begin{array}{l}\text { N.S. } \\
\text { N.S. }\end{array}$ \\
\hline
\end{tabular}


MULTIPLE REGRESSION ANALYSIS

The principals' ratings for their frequency of use and importance of the seven practices were shown by the previous ANOVA analysis to have no pattern or trend of effect when controlled for the independent variables except for two dependent variables. These two variables--ratings for the importance of the Selection of Service Delivery Patterns and ratings of the frequency of use of Parental Involvement-were found to be significant across 3 of 4 independent variables. Further analysis was conducted with the two dependent variables that showed significance in associations between three of the independent variables. This analysis would help determine if the significant ANOVAs could be more explicitly described. A stepwise multiple regression was the appropriate statistical procedure to determine if the independent variables had a significant multiplicative effect on the selected principal practices.

An analysis of variance indicated a significant difference between the principals' ratings of the importance of the Selection of Service Delivery Patterns and the percentage of student/body attending respondent's school for at least one year at the .0001 level, the percentage of at-risk youth at the .01 level and the school size at the .05 level. A stepwise multiple regression was performed to determine the relationship between the importance of the Selection of Service Delivery Patterns and the 
aforementioned predictor variables. The relationships were expressed by the multiple correlation coefficient (R) and the square of the multiple correlation coefficient $\left(R^{2}\right)$. The $R$ and $R^{2}$ for predictor variable percentage of student body attending respondent's school for at least one year were .321 and .103 respectively. The $R$ and $R^{2}$ for predictor variable percentage of at-risk youth plus the first variable were .368 and .136 respectively. The $R$ and $R^{2}$ for predictor variable school size plus the first and second variables were .370 and .137 respectively, increasing the explained variance .1\%. The coefficient of the variation describing the association between the predictor variables and the principal practice selection of Service Delivery Patterns was $R=.37, p<.05$. Only $13.7 \%$ of the variance in the ratings for the importance of the selection of service Delivery Practice can be explained by the concomitant variation in the predictor variables acting simultaneously. Even though the correlation was not due to chance, the percentage of explained variance was extremely low. Eightsix percent of the variance in the principals' ranking scores is explained by something other than these three independent variables. Typically, at least $30 \%$ of the explained variance would need to be achieved before the effect of predictor variables on a dependent variable could be considered a significant finding.

The complete results are listed in Table XV. 
TABLE XV

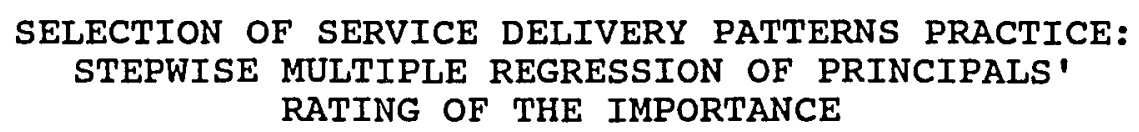

\begin{tabular}{lcccc}
\hline Predictor Variables & Step & $R$ & $R^{2}$ & $R^{2}$ Change \\
\hline $\begin{array}{l}\text { Percentage of Study Body } \\
\text { Attending Respondent's School }\end{array}$ & 1 & .321 & .103 & - \\
for at Least One Year & & & & \\
Percentage of At-risk Youth & 2 & .368 & .136 & .033 \\
School Size & 3 & .370 & .137 & .001 \\
\hline
\end{tabular}

An analysis of variance also indicated a significant difference between the principals' ratings of the frequency of use of Parental Involvement and the percentage of student body attending respondent's school for at least one year at the .01 level, the school size at the .05 level, and the percentage of student body eligible for free lunch at the .05 level. A stepwise multiple regression was attempted to determine the relationship between the importance of Parental Involvement and the aforementioned predictor variables. The predictor variables could not be entered into the regression because no significance was found. The principals' ratings of the frequency of use of Parental Involvement could not be further explained by the effect of the predictor variables. Of the principals' ratings of the importance and frequency of use of the seven 
principal practices, the importance of the practice Selection of Service Delivery Patterns and the frequency of use of the practice Parental Involvement were each shown to have significant differences with three independent variables. However, a regression analyses of each practice determined that the independent variables offered little, if any, explanation of the variance.

Both the ANOVA and the regression analysis demonstrated that the independent variables had little measurable effect on the principals' ratings of importance and frequency of use of the seven practices. Regardless of statistical scrutiny, the means of the principals' ratings could not be consistently explained simply by school demographics.

\section{Research Question \#8}

What principal practices designed to serve at-risk youth are associated with elementary schools successfully serving at-risk youth?

The association between principal practices and the principals' perception of how successfully their schools are serving at-risk youth was analyzed using a Pearson ProductMoment Correlation.

A correlation coefficient reaching a significant level $(p<.05)$ was found between the principals' perception of how successfully their schools are serving at-risk youth and the frequency of use ratings of principal influences on 
district level support. The correlation coefficient registered .316 which is a low relationship magnitude. The complete results are displayed in Table XVI. The correlation coefficient of the ratings of the importance and frequency of use of each practice, the magnitude of each relationship and the significance level are reported.

TABLE XVI

\section{ASSOCIATION OF PRINCIPAL PRACTICES WITH PRINCIPALS' PERCEPTION OF HOW SUCCESSFULLY SCHOOL SERVES AT-RISK YOUTH}

\begin{tabular}{|c|c|c|c|c|}
\hline \multirow{2}{*}{\multicolumn{2}{|c|}{$\begin{array}{l}\text { Practice } \\
\text { Principal Influences on } \\
\text { District Level Support } \\
\text { Importance of Practice } \\
\text { Frequency of Use }\end{array}$}} & \multirow{2}{*}{$\begin{array}{l}\text { Elation } \\
\text { Eicient } \\
.108 \\
.316\end{array}$} & \multirow{2}{*}{$\begin{array}{l}\begin{array}{c}\text { Relationship } \\
\text { Magnitude }\end{array} \\
\text { negligible } \\
\text { low }\end{array}$} & \multirow{2}{*}{$\begin{array}{c}\begin{array}{c}\text { Significance } \\
\text { Level } \\
\text { (Pearson's r) } \\
\text { N.S. } \\
\text { p<.01 }\end{array}\end{array}$} \\
\hline & & & & \\
\hline $\begin{array}{l}\text { Selection of Service } \\
\text { Delivery Patterns } \\
\text { Importance of Pract } \\
\text { Frequency of Use }\end{array}$ & tice & $\begin{array}{r}-.184 \\
.130\end{array}$ & $\begin{array}{l}\text { negligible } \\
\text { negligible }\end{array}$ & $\begin{array}{l}\text { N.S. } \\
\text { N.S. }\end{array}$ \\
\hline $\begin{array}{l}\text { Assignment of Personr } \\
\text { Importance of Pract } \\
\text { Frequency of Use }\end{array}$ & $\begin{array}{l}\text { nel } \\
\text { tice }\end{array}$ & $\begin{array}{l}.014 \\
.096\end{array}$ & $\begin{array}{l}\text { negligible } \\
\text { negligible }\end{array}$ & $\begin{array}{l}\text { N.S. } \\
\text { N.S. }\end{array}$ \\
\hline $\begin{array}{l}\text { A Responsive Staff } \\
\text { Development Program } \\
\text { Importance of Pract } \\
\text { Frequency of Use }\end{array}$ & tice & $\begin{array}{r}-.128 \\
.145\end{array}$ & $\begin{array}{l}\text { negligible } \\
\text { negligible }\end{array}$ & $\begin{array}{l}\text { N.S. } \\
\text { N.S. }\end{array}$ \\
\hline $\begin{array}{l}\text { School Personnel Acce } \\
\text { Importance of Pract } \\
\text { Frequency of Use }\end{array}$ & $\begin{array}{l}\text { eptar } \\
\text { tice }\end{array}$ & $\begin{array}{l}\text { ze } \\
-.158 \\
-.006\end{array}$ & $\begin{array}{l}\text { negligible } \\
\text { negligible }\end{array}$ & $\begin{array}{l}\text { N.S. } \\
\text { N.S. }\end{array}$ \\
\hline $\begin{array}{l}\text { Parental Involvement } \\
\text { Importance of Pract } \\
\text { Frequency of Use }\end{array}$ & tice & $\begin{array}{l}.034 \\
.171\end{array}$ & $\begin{array}{l}\text { negligible } \\
\text { negligible }\end{array}$ & $\begin{array}{l}\text { N.S. } \\
\text { N.S. }\end{array}$ \\
\hline $\begin{array}{l}\text { Community Involvement } \\
\text { Importance of Pract } \\
\text { Frequency of Use }\end{array}$ & tice & $\begin{array}{l}-.168 \\
-.026\end{array}$ & $\begin{array}{l}\text { negligible } \\
\text { negligible }\end{array}$ & $\begin{array}{l}\text { N.S. } \\
\text { N.S. }\end{array}$ \\
\hline
\end{tabular}


SUMMARY

Data relevant to the research questions were presented and described.

The mean and rank scores for the importance and frequency of use of all principal practices were presented and compared. Selection of Service Delivery Patterns was perceived as the most important $(\underline{M}=3.65)$ and the most frequently used $(\underline{M}=3.21)$ set of practices in serving at-risk youth. The ratings of the importance and the frequency of use of principal practices were compared. Analysis of variance (ANOVA) calculated the statistical significance of the association between the principal practices and percentage of at-risk youth, percentage of students eligible to receive free lunch, school size, and students attending current school for at least one year. Differences reaching a significant level were found between the independent variables and the importance and frequency of use ratings of several principal practices.

A stepwise multiple regression was performed to discover if the significant variance between selected principal practices and several independent variables could be more explicitly described. Some further explanation of the significant variance between variables was discovered, but not at a high enough correlation to determine reasons 
for the significant differences found after examination of the ANOVA results.

Pearson's Product-Moment coefficient of Correlation (Pearson's $r$ ) determined the relationship between the principal practices and the principals' perceptions of how successfully their schools are serving at-risk youth. No relationship magnitude registered a relationship above a low level.

Even though the statistical analysis showed some significant variation by selected variables, there was no indication of a statistical pattern or trend. The independent variables had no discernable effect on the principals' ratings of the importance and frequency of use of principal practices.

Further discussion regarding the findings are presented in chapter $V$. Chapter $V$ also presents the summary, interpretations, and recommendations. 
CHAPTER V

$$
\begin{gathered}
\text { SUMMARY, INTERPRETATIONS, AND } \\
\text { RECOMMENDATIONS }
\end{gathered}
$$

American youth who have not experienced success in public education are once again a focus of national attention. Twenty years ago, the at-risk youth concern was part of the "War on Poverty." Today, it can be defined as a war for sustaining the American democratic society. Participation in the American society is dependent more and more on education (Barr \& Parrot, 1992).

With the awareness of the relationship between education and societal success, elementary school principals are searching for effective practices which will prevent at-risk youth from becoming dropouts.

The purpose of this study was to investigate the relationship of principals' practices to the provision of service for at-risk youth. The information gained by answering the research questions supplied principals with valuable information regarding the provision of service for at-risk youth.

The seven principal practices investigated were: Principal Influences on District Level Support, Selection of Service Delivery Patterns, Assignment of Personnel, A Responsive Staff Development Program, School Personnel 
Acceptance, Parental Involvement, and Community Involvement. Differences in the ratings of the importance and frequency of use of the seven practices by principals were compared. Variables such as school size, percentage of students eligible for free lunch, percentage of students who are at-risk, percentage of students who have attended current school for at least one year, and principal's rating of how successfully their school is serving at-risk youth were also investigated.

Elementary principals employed in the metropolitan area of Portland, oregon were randomly chosen to participate in the study. Data were collected from the critical Principal Practices Profile, a survey developed by the researcher and five practicing principals. Information gathered from the survey was analyzed using a variety of statistical treatments. The discussion of the findings is separated into four parts: (a) the research questions are restated and the findings concerning each question are discussed, (b) the limitations are reviewed, (c) interpretations of the findings are presented and discussed, and (d) the recommendations are presented and discussed.

\section{FINDINGS AND DISCUSSION}

In general, the statistical analyses upheld the principals' rankings of the importance and frequency of use 
of the seven principal practices. Regardless of the independent variables that were introduced, the results disclosed no specific subgroup trend or significant variation by variable. Principals are generally in agreement regarding their ratings of the importance and frequency of use of the seven principal practices designed to assist youth at-risk of school failure. The following is a discussion of the specific findings for each research question.

\section{Research Question \#1}

What practices do principals perceive as important in serving at-risk youth in elementary schools?

In examining the seven principal practices, the means and standard deviations of the importance ratings were calculated. The means of the principals' ratings for the importance of each of the practices indicated that the principals considered all of the practices important in successfully serving at-risk youth in their schools.

When ranking the importance of these seven principal practices by their means, Selection of Service Delivery Patterns was number one, followed by A Responsive staff Development Program, School Personnel Acceptance, Assignment of Personnel, Principal Influences on District Level Support and Parental Involvement (tie), and Community Involvement Respectively. 
There is no question that the principal practices chosen for inclusion in this study are important in the provision of service for at-risk youth. The literature, practitioners, and the results from this study substantiated the practices' importance. Even though the practice Community Involvement was rated as important by the respondents, the mean of the ranking was substantially lower than those for the remaining six. The practice may not have received as high ratings by principals because the commitment necessary to receive benefits for at-risk youth from the community is oftentimes overwhelming. In the ratings for this particular practice, "importance" may be an indication of the possibly meager return for the at-risk student after a considerable effort expended by the principal.

Research Question \#2

How frequently are principal practices serving at-risk youth in use in elementary schools?

In examining the seven principal practices, the means and standard deviations of the frequency of use ratings are calculated. The means of the principals' ratings for the frequency of use of Selection of Service Delivery Patterns, Parental Involvement, School Personnel Acceptance, and A Responsive Staff Development Program indicated that the principals frequently used the practices listed above when serving at-risk youth in their schools. The means of the 
principals' ratings for the frequency of use of Principal Influences on District Level support, Assignment of Personnel, and Community Involvement indicated that the principals somewhat infrequently used the practices listed above when serving at-risk youth.

When ranking the frequency of use of these seven principal practices by their means, selection of service Delivery Patterns was number one, followed by Parental Involvement, School Personnel Acceptance, A Responsive Staff Development Program, Principal Influences on District Level Support, Assignment of Personnel, and Community Involvement respectively.

\section{Research Question \#3}

What are the differences between the principals' ratings of the importance and frequency of use of practices designed to serve at-risk youth?

In examining the seven principal practices, the means and standard deviations of the importance and frequency of use ratings were calculated.

When comparing the ranks of the importance and frequency of use ratings for each of the principal practices, the Selection of Service Delivery Patterns ranked as the number one practice on both lists and Community Involvement ranked as the number seven practice on both lists. The ranks for A Responsive Staff Development Program were 2 and 4 for importance and frequency of use 
respectively. The ranks for School Personnel Acceptance were 3 and 3 for importance and frequency of use respectively. The ranks for Assignment of Personnel were 4 and 6 for importance and frequency of use respectively. The ranks for Principal Influences on District Level Support were 5.5 and 5 for importance and frequency of use respectively. The ranks for Parental Involvement were 5.5 and 2 for importance and frequency of use respectively. The rankings of the principals' ratings for the importance and frequency of use of the explanatory items also provided information regarding the provision of service for at-risk youth.

When the explanatory items were ranked without being categorized by practice, noteworthy discrepancies were found between the principals' ratings for the importance and frequency of use. The principals rated offering student counseling as the second most important $(\underline{M}=3.80)$, but as the 21 st most frequently used $(\underline{M}=2.94)$ practice. Principals may be finding barriers when they are attempting to offer counseling for their at-risk youth. Direct service for youth, such as counseling, is difficult for principals to schedule. Counseling may not be used frequently because the demands of the principalship allow for little opportunity for consistent, meaningful service. The principals' ratings for regularly scheduling conferences with parents before or after work ranked as 9 th most 
frequently used $(\underline{M}=3.22)$ and 21 st most important $(\underline{M}=$ 3.50) practice. This discrepancy is consistent with the principals' rating for the parental involvement practice. Principals may be professionally obligated to meet with parents of at-risk youth, but do not consider it very important. It may be that principals are not recognizing the benefits parents of at-risk youth can provide for their children. Principals should be encouraged to receive training in successfully working with parents of at-risk youth in order that this resource for assisting at-risk youth does not remain untapped. Another observable discrepancy occurred between the principals' ratings of the importance, and frequency of use of providing a favorable student/teacher ratio of 20 (or less) to 1 . The importance was ranked 15 th $(\underline{M}=3.58)$, but the frequency of use was ranked 34 th $(\underline{M}=2.22)$. Budgetary constraints are probably the major determining reason for the differences. There is a high monetary cost associated with providing a favorable student/teacher ratio and few school districts are currently in a financial position to offer such an expensive service. The explanatory items were also ranked within their practice categories. Within each practice, the explanatory item rated highest in importance by the principals was also rated highest in frequency of use. Since the principals' ratings of the importance and frequency of use were not affected in any systematic way by the school demographics, 
then explanatory items are not only noteworthy, but also may provide principals with a criteria for developing, implementing, or evaluating the provision of service for atrisk youth. These items are: cultivating district administrative support for building level programs, identifying at-risk students, hiring staff who establishes rapport and develops relationships with students, providing annual training for new staff, encouraging teaching to various learning styles, notifying parents of nonattendance, and providing a newsletter for community members.

\section{Research Question \#4}

What principal practices designed to serve at-risk youth are associated with elementary school size?

The principal practices and school size were compared using an ANOVA.

Differences reaching a significant level were found between school size and the importance and frequency of use ratings of selected principal practices. An analysis of variance indicated a significant difference between the groups based on school size and the ratings of the following principal practices: importance and frequency of use of Selection of Service Delivery Patterns, importance of Assignment of Personnel, and School Personnel Acceptance.

Even though the ANOVA showed significant variation by the school size, there was no specific subgroup trend evident. The means of the principals' ratings for the 
importance and frequency of use of the seven principal practices showed little effect when controlled for the variable school size of the respondent's school.

Research Question \#5

What principal practices designed to serve at-risk youth are associated with percentages of elementary students eligible to receive free lunch?

The principal practices and percentages of elementary students eligible for free lunch were compared using an ANOVA.

Differences reaching a significant level were found between the levels of students eligible for free lunch and the frequency of use ratings of School Personnel Acceptance and Parental Involvement. Even though the ANOVA showed significant variation in the frequency of use of two principal practices by the percentages of students eligible for free lunch, there was no specific subgroup trend evident. The means of the principals' ratings of the importance and frequency of use of the seven principal practices showed little effect when controlled for the percentage of students eligible for free lunch at the respondent's school. 
Research Question \#6

What principal practices designed to serve at-risk youth are associated with percentages of at-risk youth attending elementary schools?

The principal practices and percentages of elementary students at-risk were compared using an ANOVA.

Differences reaching a significant level were found between the percentages of at-risk students and the importance and frequency of use ratings of Principal Influences on District Level Support, Selection of Service Delivery Patterns, and Community Involvement.

Even though the ANOVA showed significant variation in the importance and frequency of use of three principal practices by the percentages of students at-risk, there was no specific subgroup trend evident. The means of the principals' ratings for the importance and frequency of use of the seven principal practices showed little effect when controlled for the percentage of at-risk students enrolled at the respondent's school.

\section{Research Question \#7}

What principal practices designed to serve at-risk youth are associated with the percentages of students attending their current school for at least one year?

The principal practices and percentages of students attending their current school for at least one year were compared using an ANOVA. 
Differences reaching a significant level were found between the percentage of student attendance and the importance and frequency of use ratings of selected principal practices. An analysis of variance indicated a significant difference between the percentage of students at-risk and the ratings for the following principal practices: frequency of use of Principal Influences on District Level support, importance of selection of Service Delivery Patterns, importance and frequency of use of Assignment of Personnel, importance of A Responsive Staff Development Program, frequency of use of School Personnel Acceptance, and importance and frequency of use of Parental Involvement.

Even though the ANOVA showed significant variation in the importance and frequency of use of several principal practices by the percentages of students attending the respondent's school for at least one year, there was no specific subgroup trend evident. The means of the principals' ratings of the importance and frequency of use of the seven principal practices were affected by the percentage of students enrolled at the respondent's school for at least one year, but no clear pattern of effect was discernible.

Regression Findings and Discussion. Two principal practices warranted further analysis to discover if the significant variance could be more explicitly described. A 
stepwise multiple regression was performed to determine the relationship between the principals' ratings' of the importance of the Selection of Service Delivery Patterns and the percentage of student body attending respondent's school for at least one year, the percentage of at-risk youth, and the school size. A stepwise multiple regression was also performed to determine the relationship between the principals' ratings of the frequency of use of Parental Involvement and the percentage of student body attending respondent's school for at least one year, the school size, and the percentage of student body eligible for free lunch. Less than $14 \%$ of the variance in the principals' ratings of the importance of the practice selection of Service Delivery Patterns could be explained by the influence of the three predictor variables. No variance in the principals' ratings of the frequency of use of the practice Parental Involvement could be explained.

The regression was performed by the researcher to further support the claim that the means for the principals' ratings of the importance and frequency of use of the practices were valid regardless of the influence of several school demographic variables. Results of the regression did indeed substantiate the researcher's claim: dependent variables could not be explained by the school demographics. 
Research Question \#8

What principal practices designed to serve at-risk youth are associated with elementary schools successfully serving at-risk youth?

The association between principal practices and the principals' perception of how successfully their schools are serving at-risk youth was analyzed using a Pearson ProductMoment Correlation. One correlation coefficient reaching a significant level was found between the principals' perception of how successfully their schools are serving atrisk youth and the frequency of use ratings of principal influences on district level support; however, the relationship magnitude of the coefficient was low.

The means of the principals' ratings for the importance and frequency of use of the seven principal practices were not related to the principals' perceptions of how successfully their schools were serving at-risk youth.

It is rather disturbing that the relationship between the principals' perceptions of how successfully their schools were serving at-risk youth and the principals' ratings for the importance and frequency of use of the seven practices was due to chance. The researcher fully expected to discover a positive correlation between the professional observation and judgement of the principals' perception of their service for at-risk youth and the frequency of use of selected practices. This unexpected discovery may be 
attributed to some of the responding principals inflating their success rating. More likely, however, the surprising results could be traced to the principals defining "success" differently. Success could have been interpreted as academic, behavioral, or social success or even the maintenance or improvement of any or a combination of these skills.

\section{LIMITATIONS OF THE FINDINGS}

A number of limitations to this study were set forth in chapter III. In addition, other limiting factors may have had an impact on the findings of this study.

The survey was distributed at the beginning of the school year in August 1991. Principal responses may have been impacted by the time of year the data were collected. Responding to questions regarding a previous school year's information may have been difficult for a professional who was undoubtedly planning for a successful year to come. Timing may have affected the principals' ratings of the frequency of use of principal practices. A more complete reporting may have been achieved if the principals responded at the school year's end. In the spring, the knowledge concerning their use of practices would be at its highest level.

The use of perception, while documented in the literature as a reasonable measure, might raise questions 
about the accuracy of the results. Perceptions are difficult to quantify, even though the responses were recorded numerically. Perceptions are influenced by professional experiences, personality, and several other factors.

Narrative statements regarding the provision of service for at-risk youth were not solicited. Comments from principals may have clarified the implications exuded from the quantitative data.

The practices in this study were selected from the literature and practitioner input because of their reported relevance to serving at-risk youth. There are no doubt additional practices which could be studied, but they are presently unidentified.

\section{INTERPRETATIONS}

The unique contribution of this study was its description of seven principal practices which can assist in the provision of service for at-risk youth. It also offered some interesting insights into the demographics of elementary schools located in the Portland, Oregon metropolitan area.

McDill et al. (1986) identified characteristics of schools that are associated with a high percentage of future early leavers. The demographic information gathered from the respondents demonstrated that many principals employed 
in the metropolitan area of Portland, Oregon are faced with these same attributes when serving at-risk youth. Twenty-five percent of the respondents were principals at schools of more than 600 students. Twenty-seven percent were principals of schools that have at least $50 \%$ of the student body eligible for free lunch. Forty-one percent were principals of schools that have at least $31 \%$ of the student body at-risk of school failure. Twenty-six percent of the principals work at schools where $26 \%$ of the student body leave after only one year.

MCDill et al. (1986) also identified practices which might possibly counteract the effects of the "at-risk characteristics." Unfortunately, the practice identified as the most successful--described as Assignment of Personnel in this study--was the second least used practice by the principals. Principals may not be using this practice because they are unsure of the benefits or they have little control over the practice.

Research questions asked in this study were not extrapolated from a specific theory, but were derived from a review of the literature and input from five elementary principals. The findings of the principals' ratings of the importance and the frequency of use of the practices intended to provide services for at-risk youth and the findings from the review of the literature were not always consistent. 
Even though several researchers have noted the importance of Community Involvement when serving at-risk youth, the corresponding principals rated community Involvement consistently lower than the other practices in both the importance and frequency of use categories (Mann, 1986; McDill, Natriello, \& Pallas, 1986; Rumberger, 1983; Wisconsin Vocational studies Center, 1981). The principals' responses may not have agreed with the research because they have not discovered the benefits of Community Involvement or because their experiences with Community Involvement have not been beneficial for the at-risk youth population enrolled at their schools.

The responding principals' used the practices Principal Influences on District Level Support and Assignment of Personnel with considerably less frequency than the four most frequently used practices. Green and Baker (1986) find both of the practices to be characteristics of effective at-risk youth programs. The principals may use the practices with less frequency because they are unaware of the possible advantages to their at-risk students or because they have found little success when implementing the practices.

Hahn (1987) reported that a critical practice in the prevention of dropouts is the ability of the service provider to respond to the unique needs of each individual at-risk student. Green and Baker (1986) found that an 
essential element in the diagnoses of an at-risk student's needs is the involvement of the at-risk student's parent. The principals responding to the survey rated the practice Parental Involvement second lowest in the importance category. However, the respondents rated the practice second highest in the frequency of use category. This disparity may indicate that principals feel more of an obligatory responsibility to Parental Involvement rather than a perception that such a practice is successful in the provision of service for at-risk youth.

If the literature is indeed correct, then the principals' ratings of the importance of Parental Involvement and Community Involvement are not reflective of the practices' true importance.

The principals' ratings in this study do support the literature in the practice of Selection of Service Delivery Patterns. The explanatory items--identifying and monitoring at-risk students; identifying suspension, expulsion, and retention alternatives; and modifying curricula--were all identified in the literature as critical practices to employ when successfully serving at-risk youth (Green \& Baker, 1986; Texas Education Agency, 1988). Principals rated the Selection of Service Delivery Patterns as the most important and frequently used practice. It may have emerged as the highest rated item because it was the only practice which delineated direct service to students. Principals may 
consider their ability to actually interact wi.th children as their most important practice when providing service for atrisk youth. Selection of Service Delivery Patterns is also the only practice which is directly controlled by the elementary principal. Each of the other practices is dependent upon the action of a third party to ensure results. It may be that principals most frequently use the practices which they perceive as mostly under their control.

The statistics further demonstrate the need for identifying practices which serve students at-risk of school failure. Coupled with the findings by Bossert et al. (1982) and Dwyer and Smith (1987) that principals' practices can indeed influence schooling outcomes for students, these statistics furnish evidence to support the critical role that the principal plays in the prevention of dropouts.

\section{RECOMMENDATIONS}

\section{Implications for the}

\section{Educational Community}

All respondents included in this study were currently employed as elementary principals. The findings indicate that there is currently a need for the dissemination of additional information about principal practices which serve students at-risk of school failure. Consideration is recommended in the following areas:

1. Current practitioners and the literature identified the practices listed within the critical 
Principal Practices Profile as important when providing service for at-risk youth. Principals could use the explanatory items as criteria for developing a service delivery plan for at-risk youth or for evaluating the services currently provided for at-risk youth.

2. The low ratings of the importance and frequency of use of the practice community Involvement imply that either adequate information is not easily accessible or principals are not accessing what is available. Principals should be encouraged to participate in inservice training programs which focus on the importance and use of community Involvement in the provision of service for at-risk youth.

3. The principals' rated the frequency of use of the practices Principal Influences on District Level Support and Assignment of Personnel considerably lower than the four practices used most frequently. Principals should also be encouraged to participate in inservice training programs which focus on the use of these practices.

4. Because of the assessment made above about the low frequency of use of two practices, school district offices should be encouraged to support principals' practices in assigning personnel.

5. The study finds that the selection of service Delivery Patterns was rated as the most important and frequently used practice by principals. Principals should be encouraged to continue these practices. 
6. The demographic information identifies that several elementary schools involved in this study possessed characteristics of schools with high dropout rates. Consideration should be given to strategies and practices which can address and ameliorate these characteristics.

7. The literature and the practitioners both note the importance of all seven of the principals practices described in this study. Universities offering principal certificate programs and post-baccalaureate degrees in educational administration should be encouraged to offer training in practices which serve at-risk youth.

In Chapter I, the devastating societal and individual consequences of at-risk youth who leave the formal educational system before high school graduation were explained. The importance of the role of the elementary principal in providing services that prevent at-risk youth from becoming dropouts was additionally discussed. Though it is clearly a responsibility of the principal to meet the challenge of at-risk youth, providing services which will support the principals' efforts is a challenge that everyone else in the educational community should definitely meet.

\section{Implications for Future}

Research

This study identifies some significant findings regarding the provision of service for at-risk youth. It is the recommendation of this researcher to elaborate on the 
findings in this study within a qualitative study. There would be several benefits if this were to occur. A clearer definition of the principal practices and their effects on at-risk youth could be identified. Additional principal practices might be identified as important in providing service for at-risk youth.

A further extension of this study could be the examination of the external variables affecting the principals' practices, such as district level administration, state and local regulations, community agencies, and parental influences.

A longitudinal study could determine a relationship between elementary principal practices and at-risk students who remain in school at least through high school graduation.

A study which determines an objective measure of successfully serving at-risk youth as the dependent variable and the principal practices as the independent variable could also serve as a further extension to this study. 


\section{REFERENCES}

Ary, D., Jacobs, L., \& Razavieh, A. (1985). Introduction to research in education ( $3 \mathrm{rd}$ ed.). New York: Rinehart and Winston.

Barr, R. D., \& Parrett, W. H. (1992). At last: Hope for at-risk: A manual for schools and communities for developing programs that work for at-risk youth. Unpublished manuscript.

Barth, R. (1976). The principal and his school. National Elementary Principal, 56, 8-21.

Blumberg, A. (1987). The work of principals: A touch of craft. In W. D. Greenfield (Ed.), Instructional leadership: Concepts, issues, and controversies ( $p p$. 38-55). Boston, MA: Allyn and Bacon.

Blumberg, A., \& Greenfield, w. (1986). The effective principal: Perspectives on school leadership (2nd ed.). Boston: Allyn and Bacon.

Bossert, S., Dwyer, D., Rowan, B., \& Lee, G. (1982). The instructional management role of the principal. Educational Administration Quarterly, 18, 34-64.

Burlingame, M. (1985). Using a political model to examine principals' work. Peabody Journal of Education, $\underline{63}$ (1), 120129 .

California state Department of Education. (1986). California dropouts: A status report. Sacramento, CA: Author. (ERIC Document Reproduction Service No. ED 277 964)

Children's Defense Fund. (1990). Children 1990: A report card, briefing book, and action primer. Washington, DC: National Association for the Education of Young Children.

Cronbach, I. J. (1951). Coefficient alpha and the internal structure of tests. Psychometrika, 16, 297-334.

Cuban, L. (1988). The managerial imperative and the practice of leadership in the schools. Albany, NY: State University of New York. 
Duhon, R. M., \& Mouton, A. (1985). An investigative analysis of high dropout rates in Louisiana schools. Lake Charles, LA: McNeese State College. (ERIC Document Reproduction Service No. ED 273 633)

Dwyer, D. C. (1985). Understanding the principal's contribution to instruction. Peabody Journal of Education, 63 (1), 3-18.

Dwyer, D. C., \& Smith, L. M. (1987). The principal as explanation of school change: An incomplete story. In W. D. Greenfield (Ed.), Instructional leadership: Concepts, issues, and controversies (pp. 155-178). Boston, MA: Allyn and Bacon.

Gay, L. R. (1987). Educational research (3rd ed.). Columbus, OH: Merrill.

Getzels, J. W., \& Guba, E. G. (1954). Role, role conflict and effectiveness: An empirical study. American Sociological Review, 19, 164-175.

Getzels, J. W. , \& Guba, E. G. (1957). Social behavior and the administrative process. School Review, 65, 423-441.

Glaser, B. G., \& strauss, A. L. (1967). The discovery of grounded theory: strategies for qualitative research. Chicago, IL: Aldine.

Green, K. R., \& Baker, A. (1986). Promising practices for high-risk youth in the northwest region: Initial search. Portland, OR: Northwest Regional Educational Laboratory.

Green, R. I., \& Smith, J. (1987). A report on the student dropout retention project at East Technical High School, Cleveland, Ohio. Cleveland, OH: Cuyahoga Community College.

Griffiths, D. E. (1959) . Administrative theory. New York: Appleton-Century-Crofts.

Gruskin, S. J., Campbell, M. A. , \& Paulu, N. (1987) . Dealing with dropouts: The urban superintendents' call to action. Washington, DC: Office of Educational Research and Improvement. (ERIC Document Reproduction Service No. ED 286992 )

Hahn, A. (1987). Reaching out to America's dropouts: What to do? Phi Delta Kappan, 69 (4), 256-263. 
Hahn, A., Danzberger, J., \& Lefkowitz, B. (1987). Dropouts in America: Enough is known for action. Washington, DC: The Institute for Educational Leadership.

Hodgkinson, H. I. (1985). All one system. Washington, DC: The Institute for Educational Leadership.

Hodgkinson, H. I. (1986). Texas: The state and its educational system. Washington, DC: The Institute for Educational Leadership.

Howell, D. C. (1982). Statistical methods for psychology. Boston: Duxbury Press.

Hoy, W. K., \& Forsyth, P. B. (1986). Effective supervision. New York: Random House.

Hoy, W. K., \& Miskel, C. G. (1987). Educational administration (3rd ed.). New York: Random House.

Institute for Educational Leadership. (1986). School dropouts: Everybody's problem. Washington, DC: Author.

Jensen, G. E. (1954). The school as a social system. Educational Research Bulletin, 23, 38-46.

Kerlinger, F. N. (1973). Foundations of behavioral research. New York: Holt, Rinehart and Winston.

Krohn, B. (Ed.). (1990-1991). Washington education directory. Seattle: Barbara Krohn and Associates.

Mann, D. (1986). Can we help dropouts: Thinking about the undoable. Teachers College Record, 87 (3), 307-323.

McDill, E. L., Natriello, G., \& Pallas, A. M. (1986). A population at risk: Potential consequences of tougher school standards for student dropouts. American Journal of Education, 94 (2), 135-181.

National policy Institute. (1988). Policy discussion papers. Washington, DC: Author.

Newman, I., \& Newman, C. (1977). Conceptual statistics for beginners. Washington, DC: University Press of America.

Nie, N., Hull C., Jenkins J., Steinbrenner, K., \& Bent, D. (1985). Statistical package for the social sciences, version $x$. Chicago: SPSS Inc. 
Oregon Department of Education. (1990). Oregon school directory 1990-91. Salem, OR: Author.

Owens, R. (1987). Organizational behavior in education (3rd ed.). Englewood Cliffs, NJ: Prentice-Hall.

Pallas, A. (1989). Making schools more responsive to atrisk students (Report No. EDO-UD-89-0). New York: ERIC Clearinghouse on Urban Education. (ERIC Document Reproduction Service No. ED 315 617)

Parsons, T. (1956). Suggestions for a sociological approach to the theory of organizations $I$. Administration Science Quarterly, $1,63-85$.

Prophet, M. W., Jr. (1986). Summary paper: School leaver prevention and recovery. Paper presented at the U.S. Department of Education, Urban superintendents Network meeting, Washington, DC.

Quay, H. C., \& Allen, L. B. (1982). Truants and dropouts. In Encyclopedia of Educational Research (5th ed.) (pp. 1,958-1,961). New York: The Free Press.

Rhodes, D. C., \& McMillan, S. J., Jr. (1987, February). Refocusing schools for dropout prevention: With implications for teacher education. Paper presented at the Annual Meeting of the American Association of Colleges for Teacher Education, Arlington, VA. (ERIC Document Reproduction Service No. ED 277 698)

Rumberger, R. W. (1983). Dropping out of high school: The influence of race, sex, and family background. American Educational Research Journal, 20 (2), 199-200.

Sanacore, J. (1988). Independent reading for remedial and at risk students: The principal can make a difference. Hempstead, NY: Hofstra University, Department of Reading, Language, and Cognition. (ERIC Document Reproduction Service No. ED 298468 )

Staff of Linden Elementary School. (1988). Linden elementary advocacy program. Columbus, OH: Linden Elementary School.

Sudman, S. (1983). Applied sampling. In P. H. Rossi, J. D. Wright, \& A. B. Anderson (Eds.), Handbook of survey research (pp. 145-194). New York: Academic Press. 
Texas Education Agency. (1988). Information manual of alternatives guiding educational success (IMAGES). Austin, TX: Author.

Texas Education Agency. (1989a). Parent and community involvement. Austin, TX: Author.

Texas Education Agency. (1989b). Successful schooling for economically disadvantaged at-risk youth. Austin, TX: Author.

Tyack, D., \& Hansot, E. (1982). Managers of virtue. New York: Basic Books.

United States office of Management and Budget. (1983). Metropolitan areas and component counties. Washington, DC: U.S. Government Printing office.

United States Department of Education. (1984). Universe of public school districts. Washington, DC: U.S. Government Printing office.

Van Dalen, D. B. (1979). Understanding educational research: An introduction. New York: McGraw Hill.

Wehlage, G. G., \& Rutter, R. A. (1986). Dropping out: How much do schools contribute to the problem? Teachers College Record, 87 (3), 374-392.

Wehlage, G.G., Rutter, R.A., \& Turnbaugh, A. (1987). A program model for at-risk high school students. Educational Leadership, 44 (6), 70-73.

Wisconsin Vocational studies Center. (1981). staying in . - a dropout prevention handout, $\mathrm{k}-12$. Madison, WI: University of Wisconsin. 
APPENDIX A

PILOT STUDY 
PILOT STUDY: THE IMPORTANCE OF SELECTED FACTORS IN THE SUCCESSFUL IMPLEMENTATION OF AN AT-RISK YOUTH PROGRAM

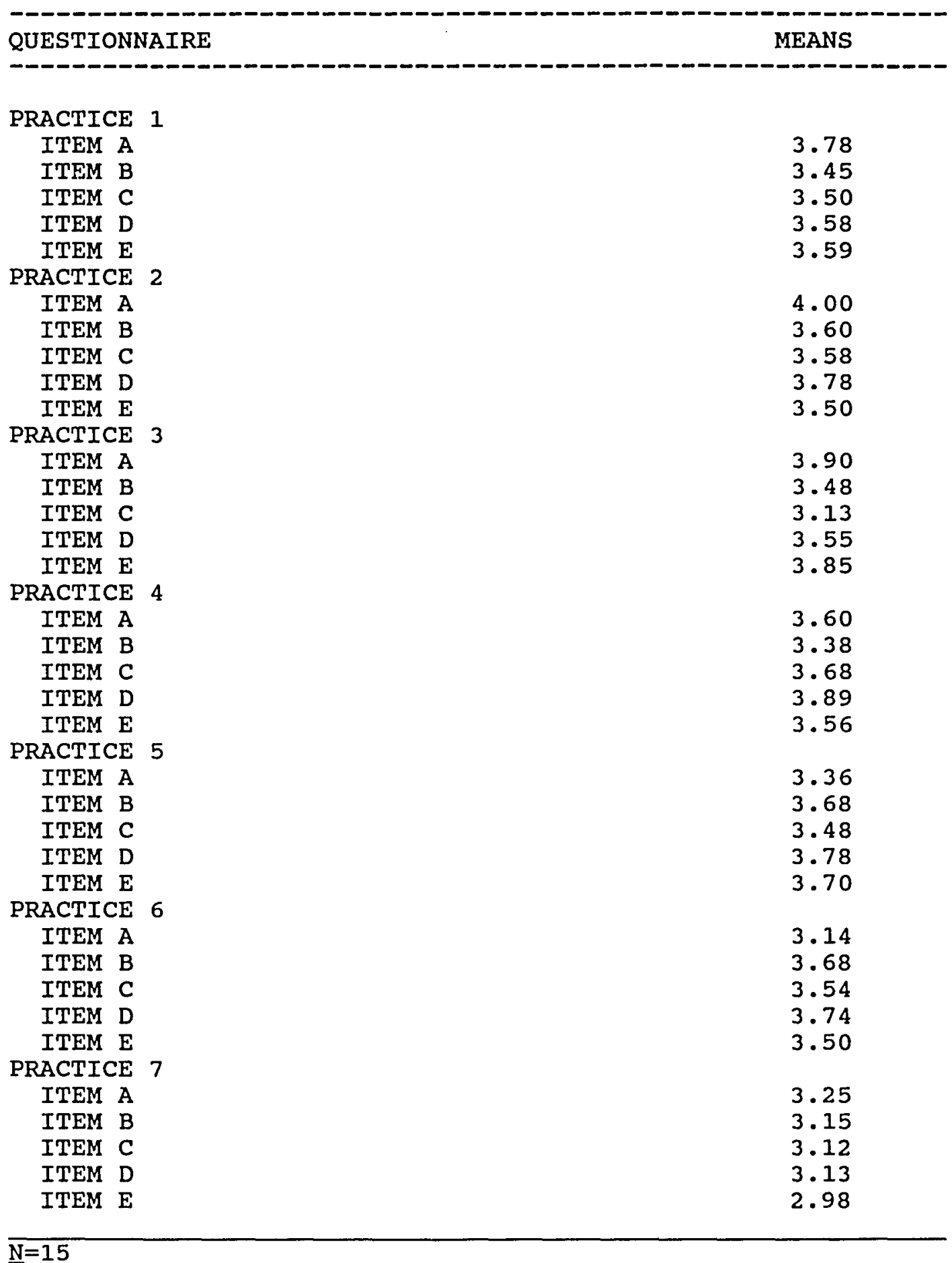


APPENDIX B

INSTRUMENT AND COVER LAETTERS 


\title{
Hillsboro Elementary Schools
}

215 S.E. SIXTH, HILLSBORO, OREGON 97120

(503) 648-1128

\begin{abstract}
AICX PATAICK
August 12, 1991

Dear Principal:

The Hillsboro Elementary School District would like to ask your assistance in identifying the critical practices that a principal can exhibit to improve the quality of service for at-risk youth. We are hoping that you will be willing to provide this assistance by completing the enclosed questionnaire and returning it by september 3, 1991.

You can be assured that this research will be conducted in accordance with ethical principles established by the American Psychological Association. The confldentiality of your response will be respected. All data will be identifled by code numbers and will only be used collectively to produce an overall profile of the findings. No individual data will be reported.

It is hoped that the findings of this study will be helpful in improving the quality of at-risk youth services. Your frontline observations are vital to this worthwhile effort. In appreciation of your help, I will be sending you a sumary of the findings upon completion of the study.

Thank you, in advance, for your time and consideration.
\end{abstract}

onteton of s rudor seruces

Respectfully yours,

Rlck Patrick

Director of Student Services 


\title{
Hillsboro Elementary Schools
}

\author{
215 S.E. SIXTH, HILLSBORO, OREGON 9712 \\ (503) $648 \cdot 1126$
}

\author{
AICKPATRICX \\ DIRECTOR OR STUDETT SEAnCES \\ September 10, 1991
}

Dear principal:

The beginning of the school year is an exceptionally busy and exciting time. Schedules are hectic and correspondence can be misplaced.

A few weeks ago, the Hillsboro Elementary School District asked you and members of your select group to participate in a study of the critical principal practices that improve the quality of service to at-risk youth. Although many responses have been received, we do not believe that we have a sample representing all of you.

We need to hear from you. Please take a few minutes and complete the enclosed questionnaire and return it to:

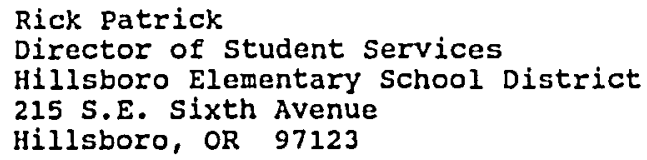

We greatly appreciate your assistance.

sincerely,

Rick Patrick

Director of student Services

Enclosure 
Fractice 5: School Personnel

a. reinforcing individualized instruction

b. fostering an awareneas of the acaderic and pocial attribute
of at-riak youth

c. requiring ensitivity of cultural

d. encouraging teaching to various

c. supporting cooperative learning Practice 6: Parental Involversent

a. upplying parente wlth
hope-learning aterial.

b. crploying various meane (hoce vinits, lettera)
of contacting parent.

c. providing parent training workuhops 12341234

d. notifying parente of nonattendance

cegularly acheduling conferences
with parents before or after work

Practice 7: Comanity Involvement

2. providing a newsletter for
corsunity nember

12341234

b. Offering a comonity tutoring

c. acquiring an active business attending regular meetinga with attending regular meetinga with
comsunity representatives

c. surveying coresunity to akk how wembera would lake to
participate and help

12341234

12341234

12341234
CRItical pRincipal practices profile

Throughout thin questionnazre, the term "at-rigk youth" 2 a ued. For conalutency in lnterpretation, please wue the at-Riak youth a atudent yo is functioning at loaet one developoental year younger than claneated, academically functioning one year below grade level, or exhibiting ether

have the purpoee of thas atudy, exclude at-riak youth who

\section{SCBOOL DRMOCRAPHICs}

1. Circle the grades which attend your school.

- Ispecifyl

2. Nusber of atudenta enrolled in your school:

3. Nurber of certified teaching ataft in your achool:

4. Percentage of atudenty eligible for free lunch

5. Ethnicity percentages of: srodents and TRAckers Aotan/Pacific Iulander

\section{African-american}

Hiepanic

Native Arerican

White (non-Hispanic)

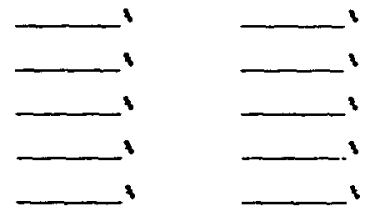

6. Percentage of at-riak youth attending your school: -

7. Percentage of atudent body suapended or expelled from

Percentage of teaching staff receiving less than a
aztiffactory teaching evaluation by you within the lant year:

9. Dietrict high school dropout rate:

10. Percentage of student body attending your achool for at
leat one echool year:
11. Please indicate how nuccessfully you feel your school it

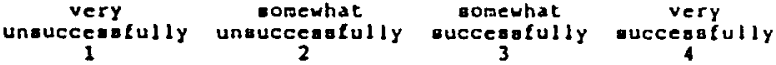


II. CRitycal paincipal pRactices

Instructiong

STEP 1: In coluen 1, indicate the extent to which you congader each practice to be important in successfully

4 - VERY IMPORTAHT

3 - SOMEHEAT IMPORTANT

1 - SOMEHEAT UNIMPORT

STEP 2: In column 2, indicate the frequency of which each STEP 2: In colven 2, indicate

1 - VERY EREQUENT USE

3 - SOMEHHAT FREQUENT OSE
1 - SOMEHHAT INFREQUENT USE
1 - VERY INEREQUENT USE

Practice 1: Principal Influences on
Digtrict Level Support cultivating district administrative

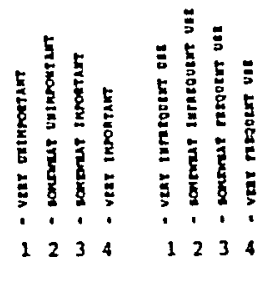

shaping district alternative
programg

12341234

developing reaponasue diatrict

d. encouraging district evaluation of at-risk youth's learning
processes and outcomes

c. integrating comunity social programs

12341234

12341234

$234 \quad 1234$
Practice 2: Selection of Service

a. identifying at-risk students

b. requiring the modification

c. identifying suapension and

expulsion alternatives

d. Donitoring gtudent performance

e. irplementing retention alternatives

Practice 3: Assignnent of Personnel

a. hiring staff who establishes rapport and develops
relationships with atudents

b. conplesenting educational staff

c. acquiring a multicthnic staff

d. providing a favorable student'
teacher ratio of 20 (or less) to 1

e. offering student counseling

Practice 4: A Responaive Staff comprehengive building plan b. offering cultural awareness

c. co-planning activities with

d. providing annual training for new ataff

e. scheduling training during

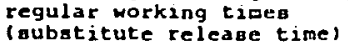

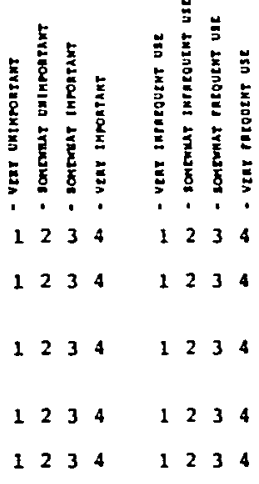

12341234

$1234 \quad 1234$

12341234

12341234

12341234

12341234

12341234

$1234 \quad 1234$

12341234

12341234 
APPENDIX C

\section{PRETEST/POSTTEST CORRELATIONS}


PILOT STUDY: PRETEST/POSTTEST CORRELATIONS

\begin{tabular}{|c|c|c|}
\hline QUESTIONNAIRE & \multicolumn{2}{|c|}{ CORRELATIONS } \\
\hline PRACTICE 1 & & \\
\hline ITEM A & .78 & .79 \\
\hline ITEM B & .84 & .89 \\
\hline ITEM C & .87 & .79 \\
\hline ITEM D & .81 & .98 \\
\hline ITEM E & .79 & .90 \\
\hline PRACTICE 2 & & \\
\hline ITEM A & .84 & .82 \\
\hline ITEM B & .82 & .86 \\
\hline ITEM $\mathrm{C}$ & .81 & .87 \\
\hline ITEM D & .84 & .90 \\
\hline ITEM E & .85 & .83 \\
\hline PRACTICE 3 & & \\
\hline ITEM A & .76 & .80 \\
\hline ITEM B & .79 & .88 \\
\hline ITEM $\mathrm{C}$ & .87 & .87 \\
\hline ITEM D & .82 & .94 \\
\hline ITEM E & .83 & .91 \\
\hline PRACTICE 4 & & \\
\hline ITEM A & .77 & .83 \\
\hline ITEM B & .86 & .81 \\
\hline ITEM C & .81 & .82 \\
\hline ITEM D & .81 & .81 \\
\hline ITEM E & .81 & .81 \\
\hline PRACTICE 5 & & \\
\hline ITEM A & .73 & .71 \\
\hline ITEM B & .88 & .83 \\
\hline ITEM $C$ & .82 & .92 \\
\hline ITEM D & 1.00 & .98 \\
\hline ITEM E & .72 & .93 \\
\hline PRACTICE 6 & & \\
\hline ITEM A & .81 & .79 \\
\hline ITEM B & .91 & .88 \\
\hline ITEM $C$ & .83 & .83 \\
\hline ITEM D & .81 & .96 \\
\hline ITEM E & .72 & .90 \\
\hline PRACTICE 7 & & \\
\hline ITEM $\AA$ & .82 & .69 \\
\hline ITEM B & .81 & .90 \\
\hline ITEM $C$ & .77 & .70 \\
\hline ITEM D & .82 & .91 \\
\hline ITEM E & .98 & 1.00 \\
\hline
\end{tabular}


PILOT STUDY SURVEY RESPONSES

How long did it take
You to finish the
survey?




\section{APPENDIX D}

RANK, MEAN SCORES, AND STANDARD DEVIATION OF IMPORTANCE AND FREQUENCY OF USE OF EXPLANATORY ITEMS

FOR EACH PRINCIPAL PRACTICE 
Rank, Mean Scores, and standard Deviation of Importance and Frequency of Use of Explanatory Items for Each Principal Practice

Practice

IMPORTANCE

Rank Mean sd
FREQUENCY OF USE Rank Mean sd

Practice 1: Principal

Influences on District

Level support

a. cultivating district administrative support for building level programs

$1 \quad 3.69 \quad .571$

$1 \quad 3.06 \quad .818$

b. shaping district alternative programs

c. developing responsive district social service programs

$\begin{array}{llllll}4 & 3.50 & .604 & 5 & 2.61 & .955\end{array}$

d. encouraging district evaluation of at-risk youth's learning processes and outcomes

$3 \quad 3.52 \quad .603$

$4 \quad 2.69 \quad .880$

e. integrating community social service programs with district programs

$\begin{array}{lll}2 & 3.58 & .549\end{array}$

$2 \quad 2.83 \quad .932$

Practice 2: Selection of Service Delivery Patterns

a. identifying at-risk students

$\begin{array}{lll}1 & 3.80 & .398\end{array}$

$1 \quad 3.58 \quad .685$

b. requiring the modification of curricula

$\begin{array}{lll}4.5 & 3.56 \quad .553\end{array}$

$\begin{array}{lll}5 & 3.03 \quad .767\end{array}$

c. identifying suspension and expulsion

alternatives

$\begin{array}{llllll}4.5 & 3.56 & .646 & 3 & 3.11 & .910\end{array}$

d. monitoring student performance

$2 \quad 3.75 \quad .495$

$\begin{array}{lll}2 & 3.25 & .799\end{array}$

e. implementing retention alternatives $\begin{array}{lll}3 & 3.58 & .598\end{array}$

$4 \quad 3.08 \quad .799$ 
Practice

IMPORTANCE

FREQUENCY OF USE Rank Mean sd Rank Mean sd

Practice 3: Assignment of Personnel
a. hiring staff who establishes rapport and develops relationships with students
$1 \quad 3.81 \quad .520$

$1 \quad 3.36 \quad .952$

b. complementing educational staff with noneducational professionals
$\begin{array}{lll}4 & 3.47 \quad .555\end{array}$
$\begin{array}{lll}3 & 2.89 & .767\end{array}$
$5 \quad 3.19 \quad .880$
$4 \quad 2.53 \quad 1.072$
$3 \quad 3.58 \quad .549$
$5 \quad 2.22 \quad 1.09$
$\begin{array}{llllll}2 & 3.80 & .571 & 2 & 2.95 & 1.11\end{array}$

c. acquiring a

multiethnic staff

d. providing a favorable student/teacher ratio of 20 (or less) to 1

e. offering student counseling

Practice 4: A Responsive Staff Development Program
a. connecting training
with a comprehensive
building plan
$3 \quad 3.64 \quad .538$
$4 \quad 3.00 \quad .820$
$\begin{array}{llllll}5 & 3.36 & .716 & 5 & 2.64 & .859\end{array}$
$\begin{array}{llllll}2 & 3.67 & .627 & 2 & 3.25 & .929\end{array}$
b. offering cultural
awareness training
c. co-planning activities with staff
d. providing annual
training for new staff
$\begin{array}{lll}1 & 3.80 & .398\end{array}$
$1 \quad 3.42 \quad .685$
e. scheduling training during regular working times (substitute release time)

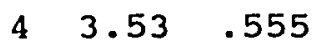
$\begin{array}{lll}3 & 3.06 \quad .813\end{array}$ 
Practice

Practice 5: School

Personnel Acceptance

a. reinforcing

individualized

instruction

b. fostering an awareness

of the academic and

social attributes of

at-risk youth

c. requiring sensitivity

of cultural differences

d. encouraging teaching to various learning styles

e. supporting cooperative learning
IMPORTANCE

Rank Mean sd
FREQUENCY OF USE

Rank Mean sd

Practice 6: Parental

Involvement

$\begin{array}{llllll}5 & 3.36 & .676 & 4 & 3.00 & .670\end{array}$

a. supplying parents with

home-learning materials $\begin{array}{lllllll}5 & 3.22 & .753 & 4 & 2.92 & .763\end{array}$

b. employing various means

(home visits, letters)

$\begin{array}{llllllll}\text { of contacting parents } & 2 & 3.70 & .520 & 5 & 2.81 & .695\end{array}$

c. providing parent

training workshops

$\begin{array}{llllll}3 & 3.53 & .555 & 5 & 2.81 & .703\end{array}$

d. notifying parents of

nonattendance

$\begin{array}{llllll}1 & 3.80 & .463 & 1 & 3.55 & .765\end{array}$

e. regularly scheduling conference with parents before or after work

$\begin{array}{llllll}4 & 3.50 & .604 & 3 & 3.22 & .789\end{array}$ 
Practice

Practice 7: Community

Involvement

a. providing a newsletter

for community members

b. offering a community

tutoring program

c. acquiring an active business partnership with school

$1 \quad 3.25 \quad .866$

$1 \quad 2.97 \quad 1.150$

$\begin{array}{lll}4 & 3.11 & .702\end{array}$

$5 \quad 2.17 \quad .902$

$2 \quad 3.20 \quad .618$

$2 \quad 2.53 \quad .990$

d. attending regular meetings with

community

representatives

e. surveying community

to ask how members

would like to

participate and help $\begin{array}{llllll}3 & 3.17 & .803 & 3 & 2.50 & 1.098\end{array}$

$\begin{array}{llllll}5 & 3.08 & .799 & 4 & 2.37 & 1.027\end{array}$
IMPORTANCE

Rank Mean sd
FREQUENCY OF USE

Rank Mean sd 
APPENDIX E

MEAN SCORES AND RANK OF IMPORTANCE AND FREQUENCY OF USE OF EXPLANATORY ITEMS 
Mean Scores and Rank of Importance and Frequency of Use of Explanatory Items

Item

(In Rank order

by Importance)

hiring staff who establishes rapport and develops relationships with students

identifying at-risk students

offering student counseling

providing annual

training for new staff

notifying parents of nonattendance

monitoring students performance

encouraging teaching to various learning styles

supporting

cooperative learning 8

employing various

means (home visits, letters) of

contacting parents

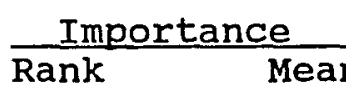

1

3.5

3.80

3.80

21

2.94

3.5

3.5

3.80

3

3.42

3.5

3.80

2

3.56

6.5

3.75

7.5

3.25

6.5

3.75

10

3.14

3.72

4.5

3.36

cultivating district administrative support for building level

programs

co-planning activities with staff
3.70

6

3.28

3.69

14.5

3.06

11

3.67

7.5

3.25 


\section{Item \\ (In Rank Order \\ by Importance)}

$\frac{\text { Importance }}{\text { Rank }}$

connecting training with a comprehensive building plan

fostering an awareness of the academic and social attributes of at-risk youth

integrating community social service programs with district programs 15

12.5 3.64

3.64

12.5

3.64

18.5

3.00

implementing retention

alternatives

providing a

favorable student/

teacher ratio of

20 (or less) to 1

15

3.58

34

2.22

requiring the modification of curricula

17.5

3.56

17

3.03

identifying

suspension and expulsion

alternatives

scheduling training

during regular

working times

(substitute release

time)

19.5

3.53

14.5

3.06

providing parent

training workshops

19.5

3.53

25

2.81

encouraging district evaluation of at-risk youth's learning processes and outcomes
21

3.52

27

2.69 
Item

(In Rank Order

by Importance)

$\frac{\text { Importance }}{\text { Rank Mean }}$

regularly scheduling

conferences with

parents before or

after work

22.5

3.50

3.50

29

$2 \cdot 61$

servicet social

22.5

complementing

educational staff

with noneducational

professionals

24

3.47

23

2.89

shaping district alterative programs

requiring sensitivity

of cultural

differences

26

3.42

16

3.05

offering cultural

awareness training

27.5

3.36

28

2.64

reinforcing

individualized

instruction

27.5

3.36

18.5

3.00

providing a newsletter for

community members

3.25

20

2.97

supplying parents with home-learning materials

3.22

22

2.92

acquiring an active business partnership with school

30.5

2.53

acquiring a

multiethnic staff

3.19

30.5

2.53

attending regular meetings with community

representatives
3.17

32

2.50 
Item

(In Rank order

by Importance)

offering a

community tutoring program

surveying community

to ask how members

would like to

participate and

help
Importance

Rank

Mean

34

3.11

35

3.08
33

2.31

Frequency of Use

Rank

35

$2 \cdot 17$

Mean

.17 